\title{
Recovery of silicon from silica fume
}

\author{
M. Barati, S. Sarder, A. McLean and R. Roy \\ Version Post-print/Accepted Manuscript \\ Citation Barati, M., S. Sarder, A. McLean, and R. Roy. "Recovery of silicon from \\ (published version) silica fume." Journal of Non-Crystalline Solids 357, no. 1 (2011): 18-23. \\ DOI: 10.1016/j.jnoncrysol.2010.09.079 \\ Copyright/License \\ (c) (1) $\Theta$ This work is licensed under the Creative Commons \\ By NC ND Attribution-NonCommercial-NoDerivatives 4.0 \\ International License. To view a copy of this license, visit \\ http://creativecommons.org/licenses/by-nc-nd/4.0/.
}

How to cite TSpace items

Always cite the published version, so the author(s) will receive recognition through services that track citation counts, e.g. Scopus. If you need to cite the page number of the author manuscript from TSpace because you cannot access the published version, then cite the TSpace version in addition to the published version using the permanent URI (handle) found on the record page.

This article was made openly accessible by $U$ of $T$ Faculty. Please tell us how this access benefits you. Your story matters. 


\title{
Recovery of Silicon from Silica Fume
}

\author{
M. Barati*, S. Sarder, A. McLean, R. Roy \\ University of Toronto, Dept. of Materials Science and Engineering \\ 140 - 184 College Street, Toronto, ON \\ Canada M5S 3E4 \\ Tel: (416) $978-5637$ \\ Fax: (416) $978-4155$ \\ Email: mansoor.barati@utoronto.ca
}

Feasibility of producing high purity silicon from amorphous silica fume, using a low temperature magnesiothermic reduction was demonstrated. Commercial silica fume containing $97.5 \%$ amorphous silica was first purified by acid leaching and roasting to remove large quantities of transition metals and carbon. The product was then reduced using magnesium as the reductant. Effect of the amount of reductant, initial temperature, and dwell time were investigated on the quantity and type of the reaction products. The optimum reduction conditions were decided based on the maximum yield of the $\mathrm{Si}$ metal. These corresponded to $\mathrm{Mg} / \mathrm{SiO}_{2}$ molar ratio of 2.0, preheating temperature of $750{ }^{\circ} \mathrm{C}$, and holding time of 2 hours. High purity silicon (>99 wt\%) containing $<3$ ppmw B and 12 ppmw $\mathrm{P}$ was obtained after leaching-purification of the reduction products, showing that the material is superior to metallurgical grade silicon, for use as solar-grade silicon feedstock. 


\section{INTRODUCTION}

Silica fume, sometimes referred to as Microsilica ${ }^{(\mathrm{R}) 1}$, consists of very fine amorphous $\mathrm{SiO}_{2}$ particles and is generated as a by-product in silicon metal and ferrosilicon manufacturing processes.

Reactions (1) to (3) summarize the basic steps involved in the formation of silica fume. During the carbothermic reduction of silica to silicon in the electric furnace (Reaction 1), silicon monoxide gas is also produced at the process temperatures typically exceeding $1800{ }^{\circ} \mathrm{C}$ (Reaction 2). Silicon monoxide escapes the furnace with other gases and is oxidized upon mixing with air to form fine particles of silica (Reaction 3). Condensed silica that is typically noncrystalline is then collected with other dust and condensed particles in the gas cleaning system.

$$
\begin{gathered}
\mathrm{SiO}_{2}+2 \mathrm{C}=\mathrm{Si}_{(l)}+2 \mathrm{CO}_{(g)} \\
\mathrm{SiO}_{2}+\mathrm{C}=\mathrm{SiO}_{(g)}+\mathrm{CO}_{(g)} \\
\left.\mathrm{SiO}_{(g)}+1 / 2 \mathrm{O}_{2}=\mathrm{SiO}_{2} \text { (silica fume }\right)
\end{gathered}
$$

A silicon furnace produces between $200-400 \mathrm{~kg}$ of silica fume per tonne of silicon metal, $[1,2]$, representing $8-15 \%$ of the quartz feed. The material has typically a specific surface area (SSA) of $15-30 \mathrm{~m}^{2} / \mathrm{g}$, particle size smaller than $1 \mu \mathrm{m}$, and $\mathrm{SiO}_{2}$ content greater than $85 \mathrm{wt} \%$ [3]. Because of such characteristics, silica fume exhibits pozzolanic properties, making it a suitable addition to high strength concretes [4], where it is primarily used. The present work aims at recovering high purity silicon from silica fume, as an alternative use of the material, and also investigating the suitability of the resultant silicon as feedstock for producing solar grade silicon (SoG-Si).

\footnotetext{
${ }^{1}$ Microsilica is the trade name of silica fume by Elkem
} 
In the past decade, the PV industry has experienced a growth rate of over $30 \%$, increasing the demand for SoG-Si substantially. A variety of processing routes are being investigated to achieve the required purity of $6 \mathrm{~N}(99.9999 \%)$ while keeping the cost below $\$ 15 / \mathrm{kg}$ [5]. One of the approaches towards production of SoG-Si is utilizing high purity starting materials to reduce the contamination of the silicon product. Amongst the materials investigated are ultrapure quartz [6] and rice husk ash [7-10] and a variety of reductants including carbon black, magnesium and calcium.

Formation of silica fume from the gas phase suggests that it may not be significantly contaminated with those impurities that are not highly volatile at the furnace temperature. Therefore, it is expected that silica fume could be a high purity source for SoG-Si feedstock. A mass balance study by Myrhaug and Tveit [11] confirms that the distribution of various elements between silica fume and silicon metal is largely consistent with their boiling temperatures. In particular, only $25 \%$ of phosphorus and $5 \%$ of boron ended up in the off-gas. Moreover, it is anticipated that the majority of the impurities can be removed from silica, by a simple acid leaching step, on the assumption that they are likely to condense at temperatures different from the oxidation of silicon monoxide, and are thus not intimately mixed with $\mathrm{SiO}_{2}$ particles. In order to investigate the potential use of silica fume for the production of high purity silicon, the current research was undertaken. A hybrid process consisting of hydrometallurgical and pyrometallurgical steps was developed on a laboratory scale. The process steps and optimized conditions of each will be discussed in this article.

\section{EXPERIMENTAL PROCEDURE}

The silica fume of Norwegian origin was first characterized to determine physical properties as well as chemical composition. The major components were quantified by X-ray 
fluoroscopy while the trace elements were measured by ICP-MS analysis. X-ray diffraction (XRD) was performed to determine the crystal structure of the major components and the total carbon content was quantified using a LECO analyzer. The material was also subjected to particle size analysis by Laser diffraction (using a Malvern S Mastersizer) and the specific surface area was determined with the BET method [12], using a SA3100 Surface Area and Pore Size Analyzer (Coulter).

The process for extraction of $\mathrm{Si}$ from silica fume relies on three major treatments; purification of silica fume, conversion of purified $\mathrm{SiO}_{2}$ to silicon (i.e. reduction), and recovery of $\mathrm{Si}$ from the reduction products.

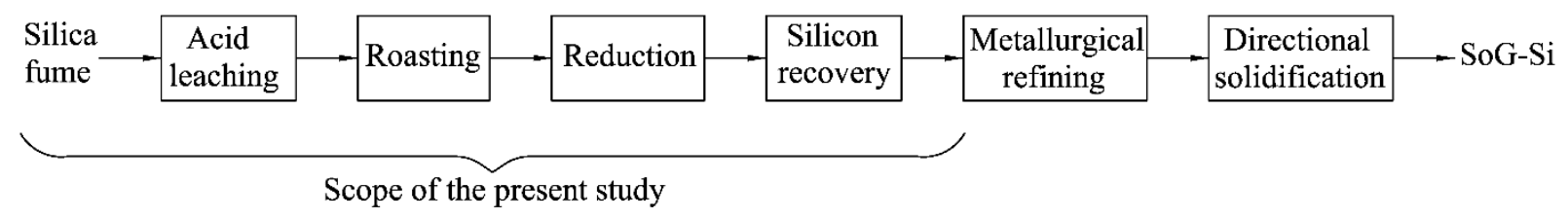

Figure 1 depicts the detailed process flow diagram. The purification consists of two subprocesses; acid leaching for removing the soluble impurities, followed by high temperature roasting for evaporation and combustion of the volatile matter and carbon. The leaching purification was carried out by dispersing SF in a $10 \mathrm{wt} \%$ hydrochloric acid solution for $1-4$ hours at 60 and $90{ }^{\circ} \mathrm{C}$. The leach residue with minimum overall impurity was selected for roasting. The solids were heated to $700{ }^{\circ} \mathrm{C}$ in a muffle furnace in the presence of air and maintained at this temperature for 2 hours. 


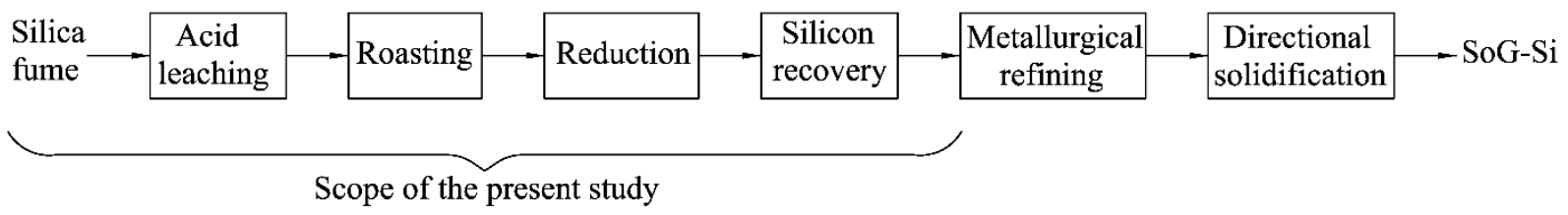

Figure 1. Process flowsheet for production of SoG-Si from silica fume .

For reduction of purified silica fume, metallic reductants were preferred over carbon to lower the temperature of the reduction and also avoid contamination of the silicon product with the impurities associated with carbon. Low temperature reduction of SF is beneficial in that operation is easier, also the large surface area of the $\mathrm{SiO}_{2}$ particles are preserved so that the product will remain responsive to subsequent leaching treatment. Magnesium was selected as the reductant by considering factors such as cost, availability, ease of removing the reduction byproducts, and the effect of residual metal on silicon properties. To determine the minimum temperature required to activate the reactions, a $60 \mathrm{mg}$ mixture of magnesium and silica fume was heated to $1150^{\circ} \mathrm{C}$ at a uniform rate of $10^{\circ} \mathrm{C} / \mathrm{min}$, in a differential thermal analyzer (Netzsch 
STA-409). The reduction onset temperature was identified by a sharp heat release peak at around

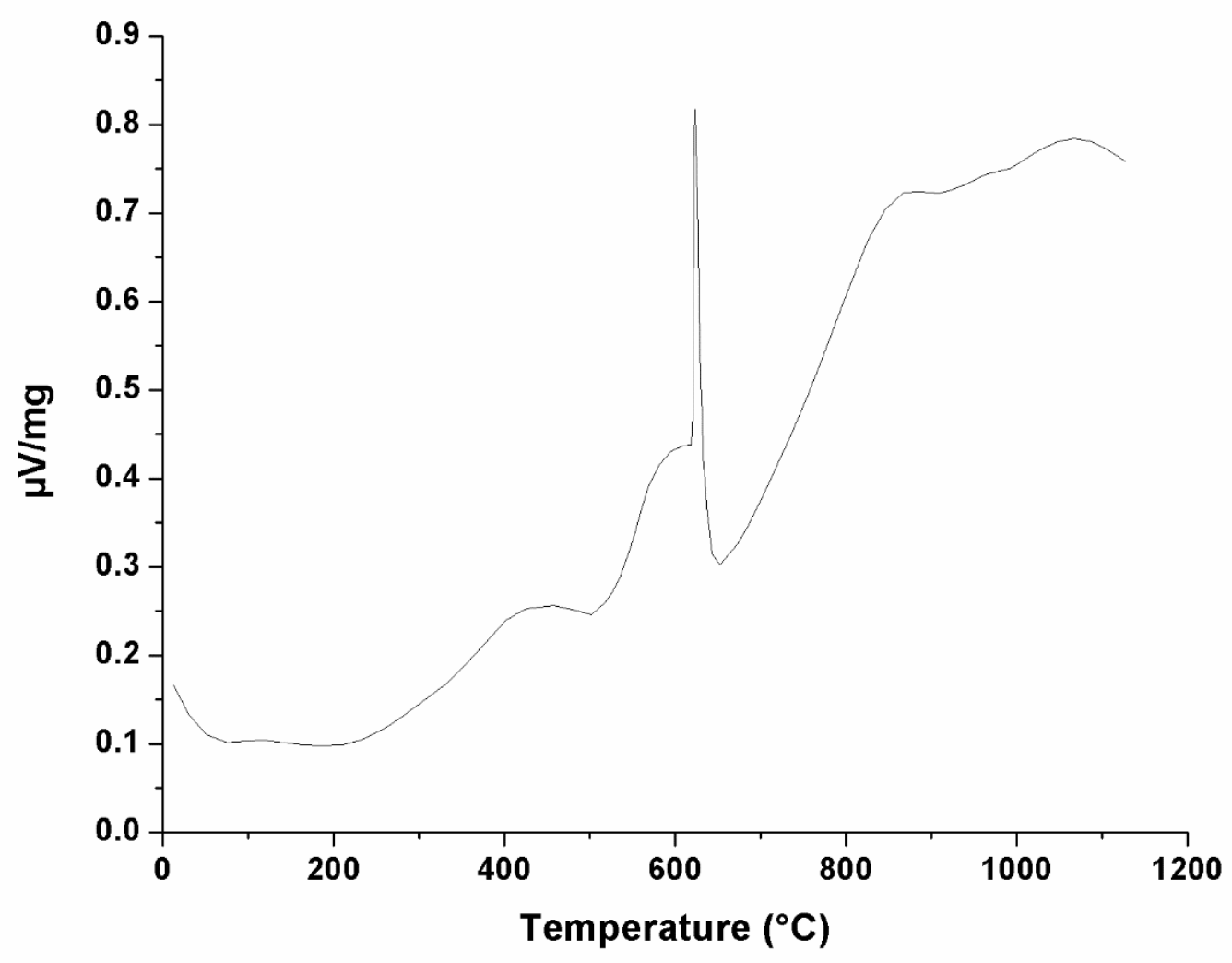

$620{ }^{\circ} \mathrm{C}($

Figure 2). 


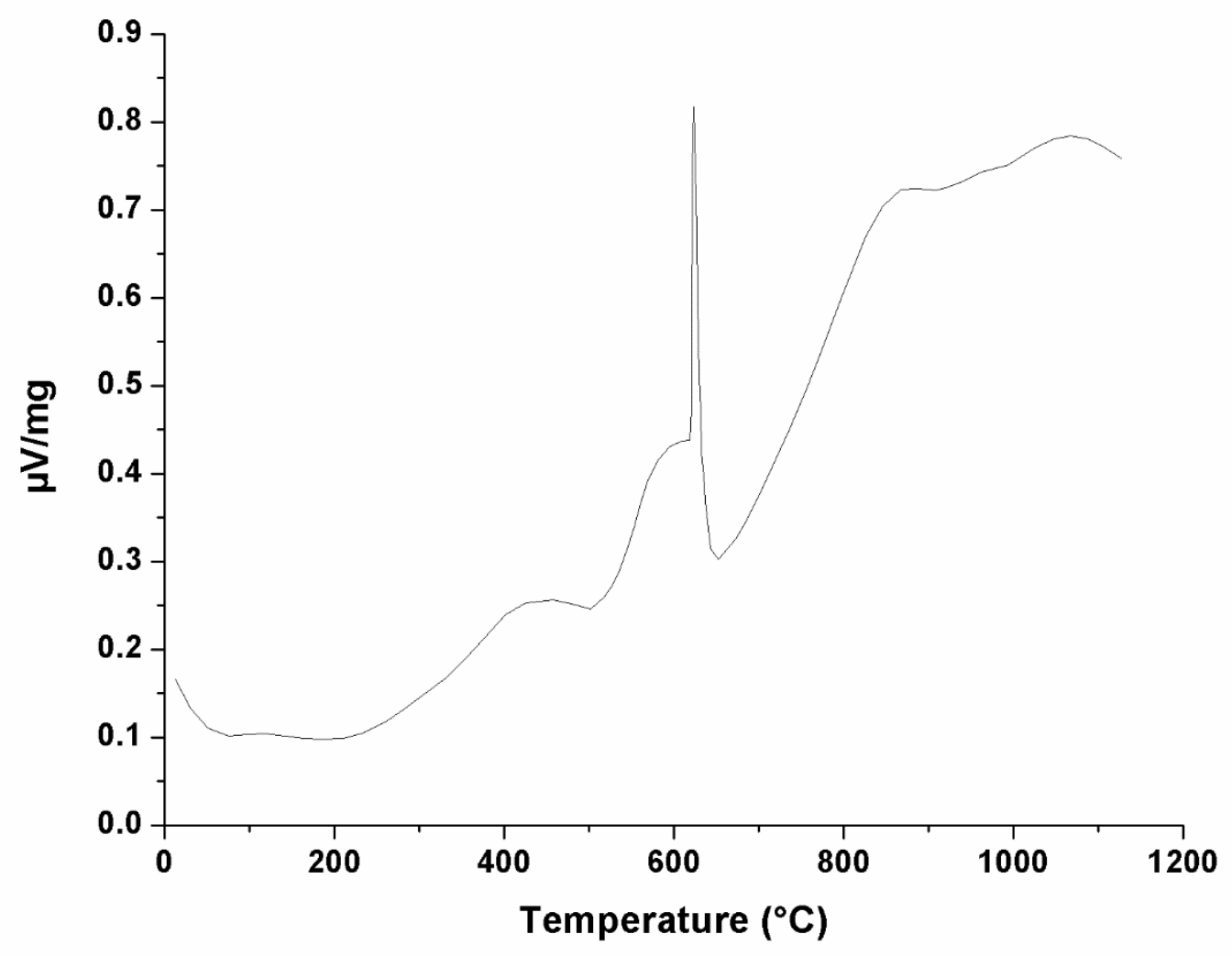

Figure 2. DTA spectrum for a mixture of silica fume and $\mathrm{Mg}$.

For the reduction experiments, mixtures of purified silica fume and $\mathrm{Mg}$ granules of $98 \%$ purity (Sigma Aldrich, Canada) with appropriate ratios were prepared. Batches of $2 \mathrm{~g}$ were loaded into an alumina tube that was inserted inside a steel capsule. The reaction cell was then placed inside a muffle furnace and heated at the rate of $5{ }^{\circ} \mathrm{C} / \mathrm{min}$ to the target temperature. After a pre-set duration, the furnace was cooled to room temperature. The reaction products were analyzed by XRD to establish the mineralogical composition and the quantity of each phase was determined by processing the XRD patterns using the Rietveld method [13].

The recovery of $\mathrm{Si}$ from the reaction products required dissolution of the by-product phases including $\mathrm{MgO}, \mathrm{Mg}_{2} \mathrm{SiO}_{4}, \mathrm{Mg}_{2} \mathrm{Si}$, and un-reacted silica. This was achieved by two stages of leaching. In the first stage, most of the magnesium-containing compounds were removed by hydrochloric acid. The effects of $\mathrm{HCl}$ concentration $(1,2$, and $4 \mathrm{M})$, temperature $\left(30-60^{\circ} \mathrm{C}\right)$ and 
reaction time (10-60 minutes) were investigated on the extraction kinetics of $\mathrm{Mg}$ compounds. Acetic acid $\left(\mathrm{CH}_{3} \mathrm{COOH}\right)$ was added at a fixed concentration of $25 \mathrm{wt} \%$ to enhance the wetting behaviour of the fine particles, by lowering the surface tension of the aqueous solution. The second stage of acid leaching was carried out to remove any $\mathrm{SiO}_{2}$ and remaining $\mathrm{Mg}_{2} \mathrm{SiO}_{4}$, using a mixture of $\mathrm{HF}(4.8 \mathrm{wt} \%)$ and acetic acid $(25 \mathrm{wt} \%)$ for 1 hour at $70{ }^{\circ} \mathrm{C}$. The recovered silicon was thoroughly rinsed with de-ionized water and digested in a mixture of $\mathrm{HF}$ and $\mathrm{HNO}_{3}$ for analysis by ICP-AES.

\section{RESULTS AND DISCUSSION}

\subsection{Characteristics of silica fume}

Table 1 presents the chemical analysis of as-received silica fume used in this work. For comparison, the analysis of rice husk ash from a parallel study is provided. The silica fume is of higher purity and is therefore a more suitable feed material for generation of SoG-Si.

Particle size analysis
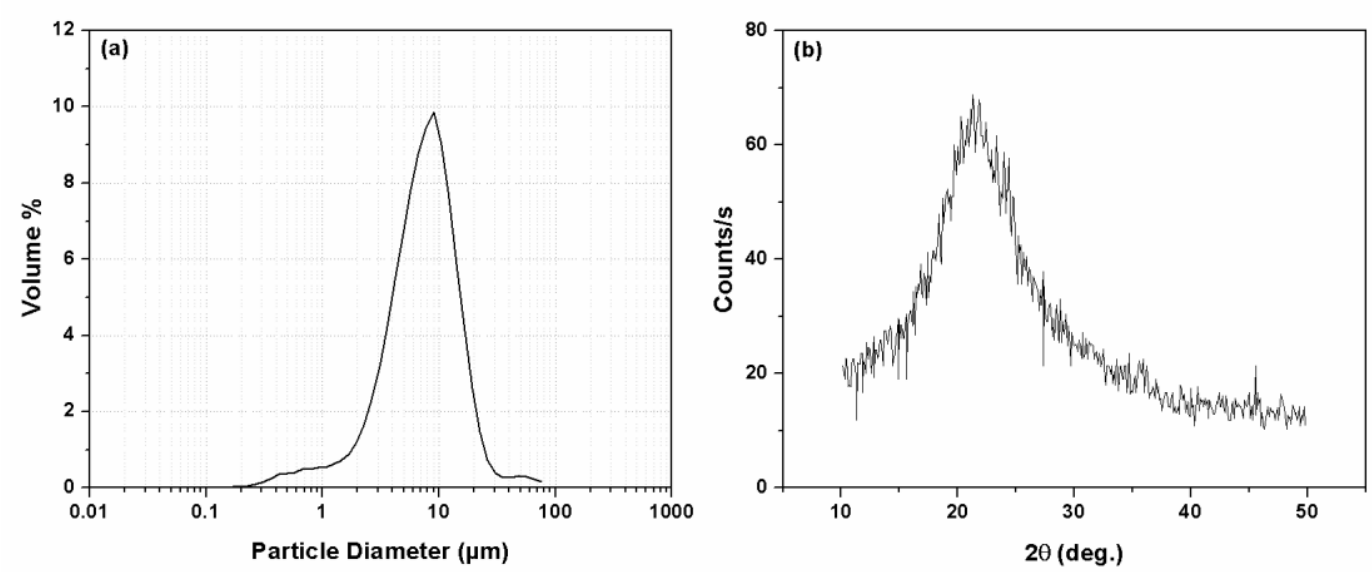

Figure 3a) shows a bell-shape distribution with mean particle size of $9 \mu \mathrm{m}$. Specific surface area measurement indicated a large specific surface area of $17.8 \mathrm{~m}^{2} / \mathrm{g}$. This is 
advantageous for surface-sensitive treatment processes such as acid leaching. X-ray diffraction
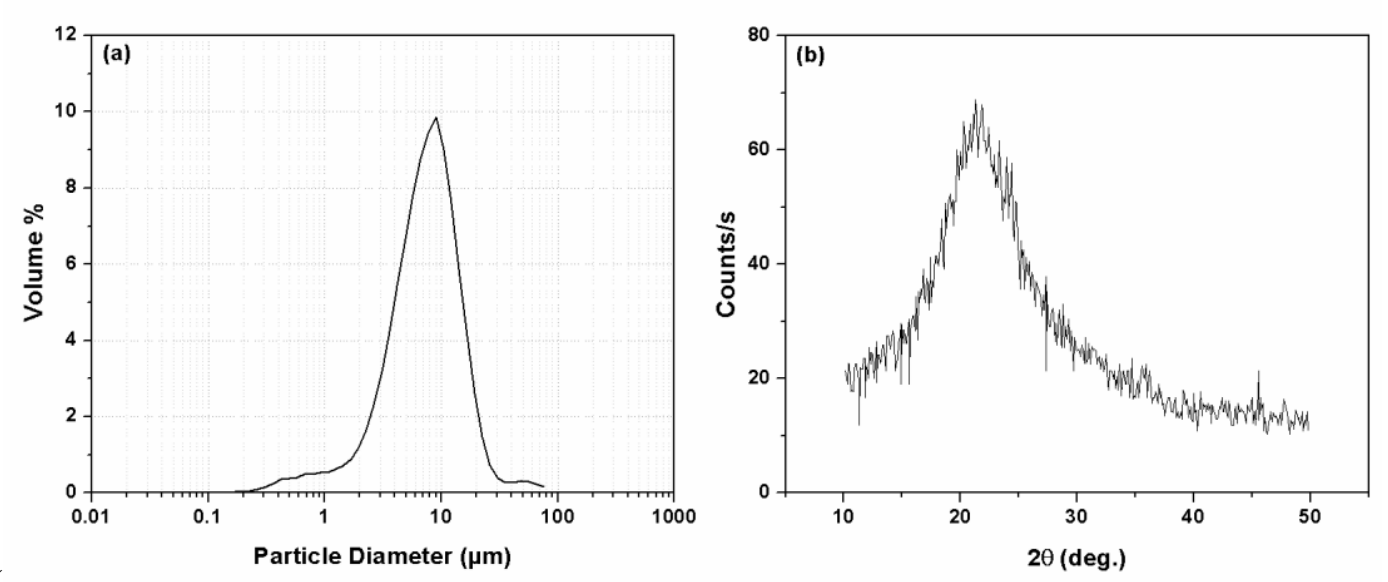

analysis (

Figure $3 b$ ) provided a spectrum with a broad peak around $2 \theta=20^{\circ}$, confirming the amorphous structure of the material.

Table 1. Chemical analysis of silica fume and rice husk ash

\begin{tabular}{lccc}
\hline Component & Unit & Silica Fume & $\begin{array}{c}\text { Rice Husk Ash } \\
{[\mathbf{1 0}]}\end{array}$ \\
\hline $\mathbf{P}$ & & & 1600 \\
$\mathbf{B}$ & ppmw & 294 & 51 \\
$\mathbf{A l}$ & ppmw & $<2$ & 4000 \\
$\mathbf{F e}$ & ppmw & 2094 & 2400 \\
$\mathbf{K}$ & ppmw & 1603 & 7900 \\
$\mathbf{C a}$ & ppmw & 7265 & 3300 \\
$\mathbf{M g}$ & ppmw & 1161 & 1600 \\
$\mathbf{M n}$ & ppmw & 3004 & 294 \\
$\mathbf{C}$ & ppmw & 93 & 1.87 \\
$\mathbf{S i O}$ & wt\% & 0.50 & 91.5 \\
\hline
\end{tabular}



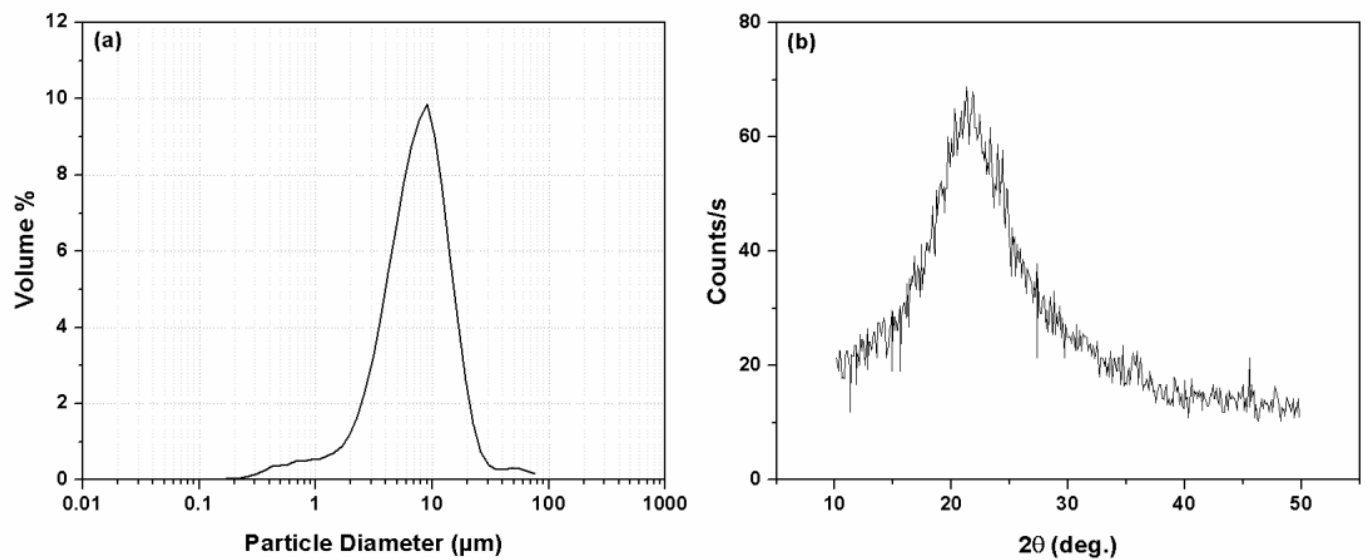

Figure 3. (a) Particle size distribution and (b) XRD spectrum of as-received silica fume.

\subsection{Purification of silica fume}

\subsubsection{Leaching Treatment}

The majority of the impurities associated with silica fume such as phosphorus, aluminum, iron, calcium, magnesium, sodium and potassium exist as oxides, although because of their low concentration their representative peaks may not be revealed by XRD analysis [14]. It is anticipated that some of the oxide impurities can be removed by acid leaching. The efficiency of this treatment was evaluated by normalizing the impurity concentration with respect to the initial 
concentration, and comparing the value for various conditions (

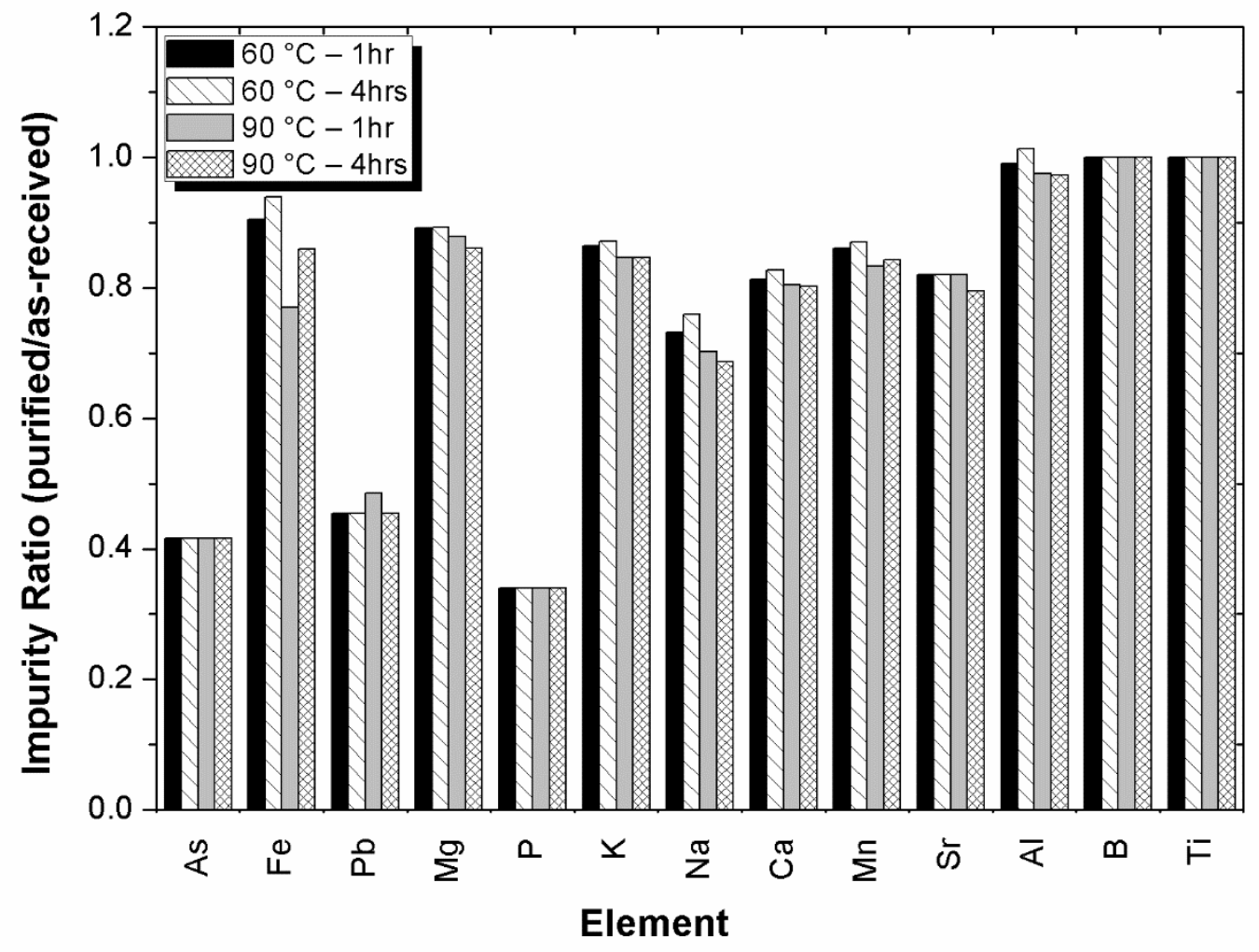

Figure 4). The results indicate that there is reduction in the concentration of majority of the impurities. 


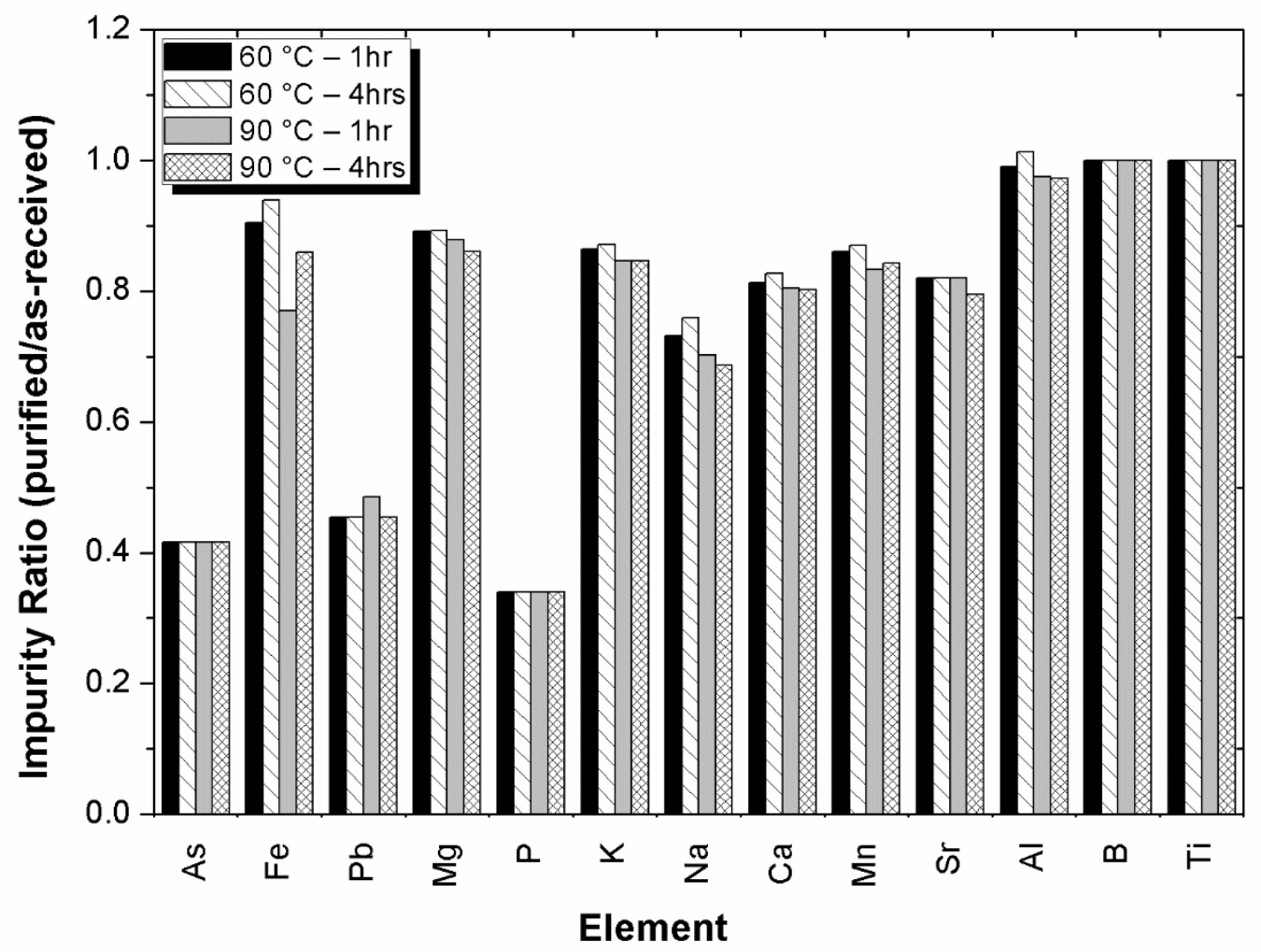

Figure 4. Effect of leaching treatment on removal of impurities.

\subsubsection{Roasting}

The leach residue with minimum impurity level was roasted as described earlier. A relatively low temperature of $700{ }^{\circ} \mathrm{C}$ was selected to maintain the amorphous structure of silica. On roasting, the material changed from a greyish colour to white, while carbon was reduced from $0.5 \mathrm{wt} \%$ to $0.17 \mathrm{wt} \%$.

The purification process increased the SSA to $27.2 \mathrm{~m}^{2} / \mathrm{g}$, due to the formation of micropores on the particles caused by acid leaching and combustion of carbon. The mean particle size remained the same.

\subsection{Reduction}

The reduction experiments included investigating the effects of temperature $\left(750-950{ }^{\circ} \mathrm{C}\right)$, hold time (1-3 hours) and magnesium to silica molar ratio (1.5-3.0) in order to establish the 
conditions that yield the maximum amount of silicon. The reaction products typically contained elemental silicon, magnesia $(\mathrm{MgO})$, and magnesium silicide $\left(\mathrm{Mg}_{2} \mathrm{Si}\right)$ as the major phases together with minor amounts of $\mathrm{Mg}_{2} \mathrm{SiO}_{4}$ and $\mathrm{SiO}_{2}$. The X-Ray diffractograms for various experimental conditions were obtained and later quantified using the Rietveld method. As an example, the XRD results for samples with various ratios of $\mathrm{Mg}$ to silica (heated to $750{ }^{\circ} \mathrm{C}$ and held for 2 hours) are displayed in

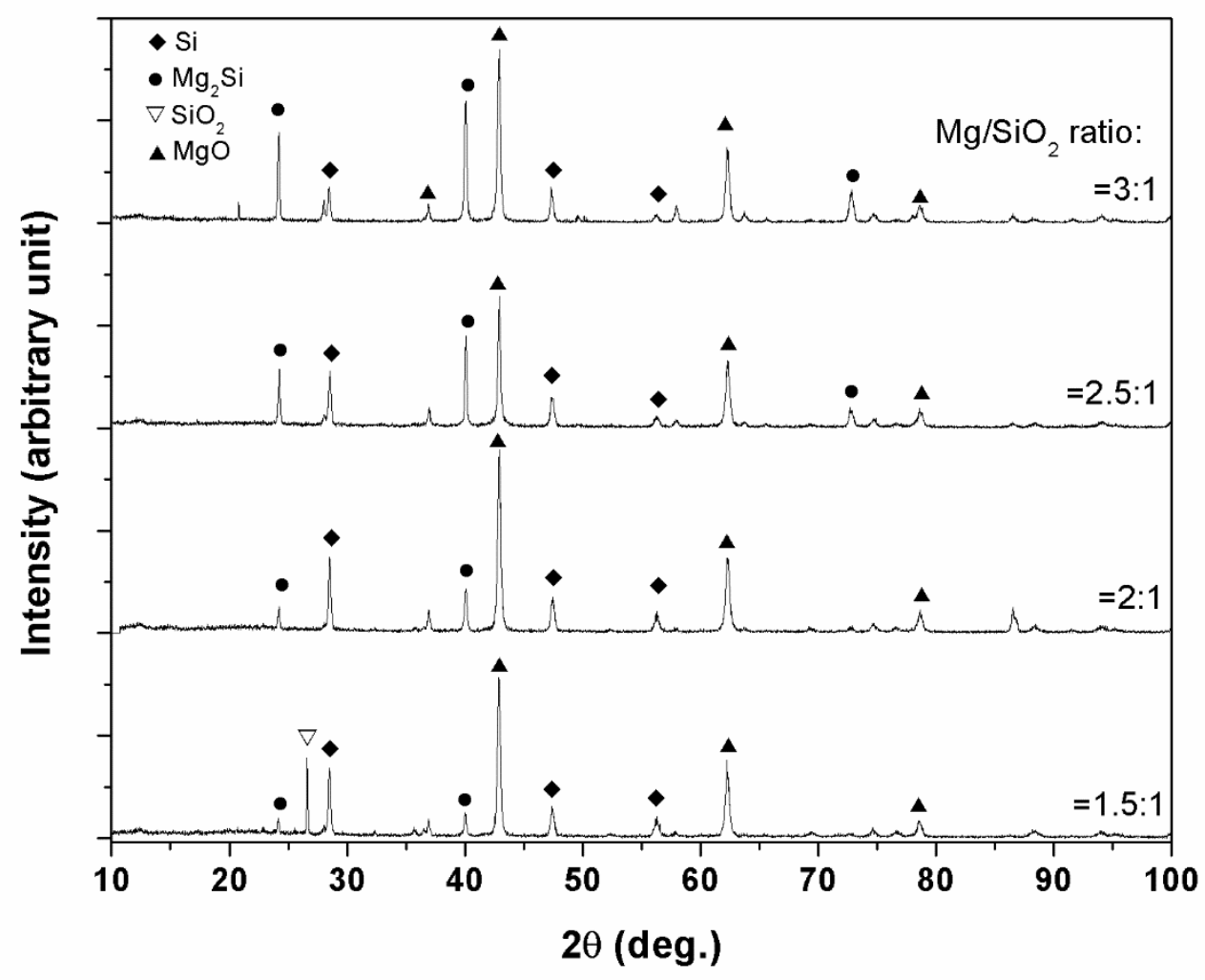

Figure 5. As seen from the relative heights of the peaks, the formation of $\mathrm{MgO}, \mathrm{Mg}_{2} \mathrm{Si}$ and silicon is affected by the ratio of $\mathrm{Mg} / \mathrm{SiO}_{2}$. For example, when the ratio is $3: 1 \mathrm{Mg}_{2} \mathrm{Si}$ peaks are very prominent, whereas by reducing $\mathrm{Mg}$, their relative intensity is decreased. Clearly, a decrease in the amount of magnesium silicide gives rise to producing larger amounts of Si. The Si yield was calculated from the quantified XRD results and used as a measure for the optimum reduction conditions, as will be discussed later. 


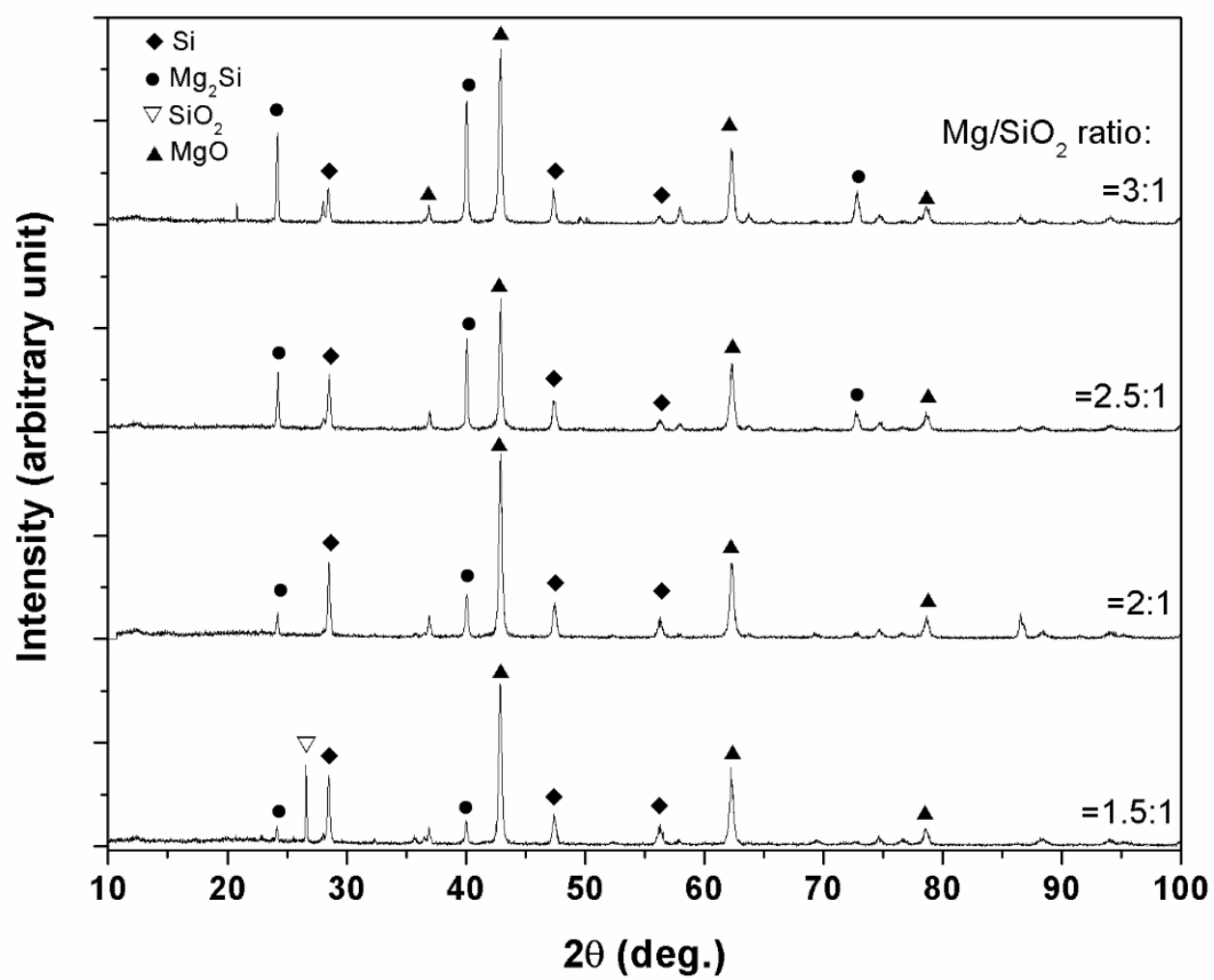

Figure 5. Effect of magnesium/silica ratio on the XRD spectrum of samples reduced at $750^{\circ} \mathrm{C}$ for 2 hours.

\subsection{Recovery of silicon from reaction products}

The recovery of silicon from reaction products consisted of a two-step acid leaching to remove magnesium-containing compounds and unreduced silica. Both $\mathrm{MgO}$ and $\mathrm{Mg}_{2} \mathrm{Si}$ are soluble in $\mathrm{HCl}$; magnesium silicide reacts with $\mathrm{HCl}$ solution and produces silane gas [15] that combusts spontaneously in the presence of air. On the other hand, $\mathrm{MgO}$ is readily dissolved in dilute $\mathrm{HCl}$ and remains in the solution as $\mathrm{MgCl}_{2}$. The effect of concentration of $\mathrm{HCl}$ on the 
dissolution of a mixture of magnesium compounds was investigated and the results are shown in

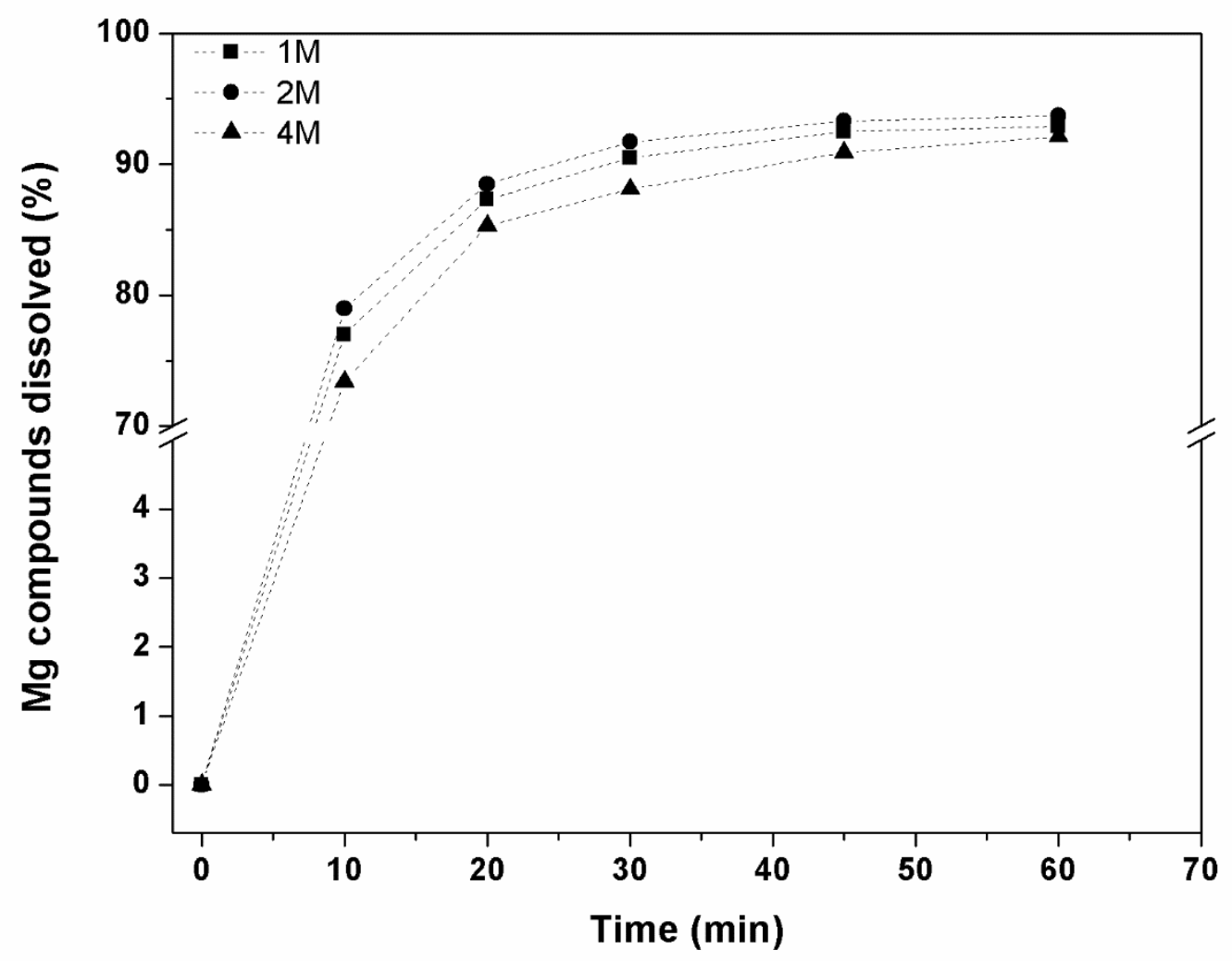

Figure 6. Error! Reference source not found.The highest dissolution of magnesium compounds was observed for $2 \mathrm{M} \mathrm{HCl}$ solution followed by $1 \mathrm{M}$ and $4 \mathrm{M}$. 


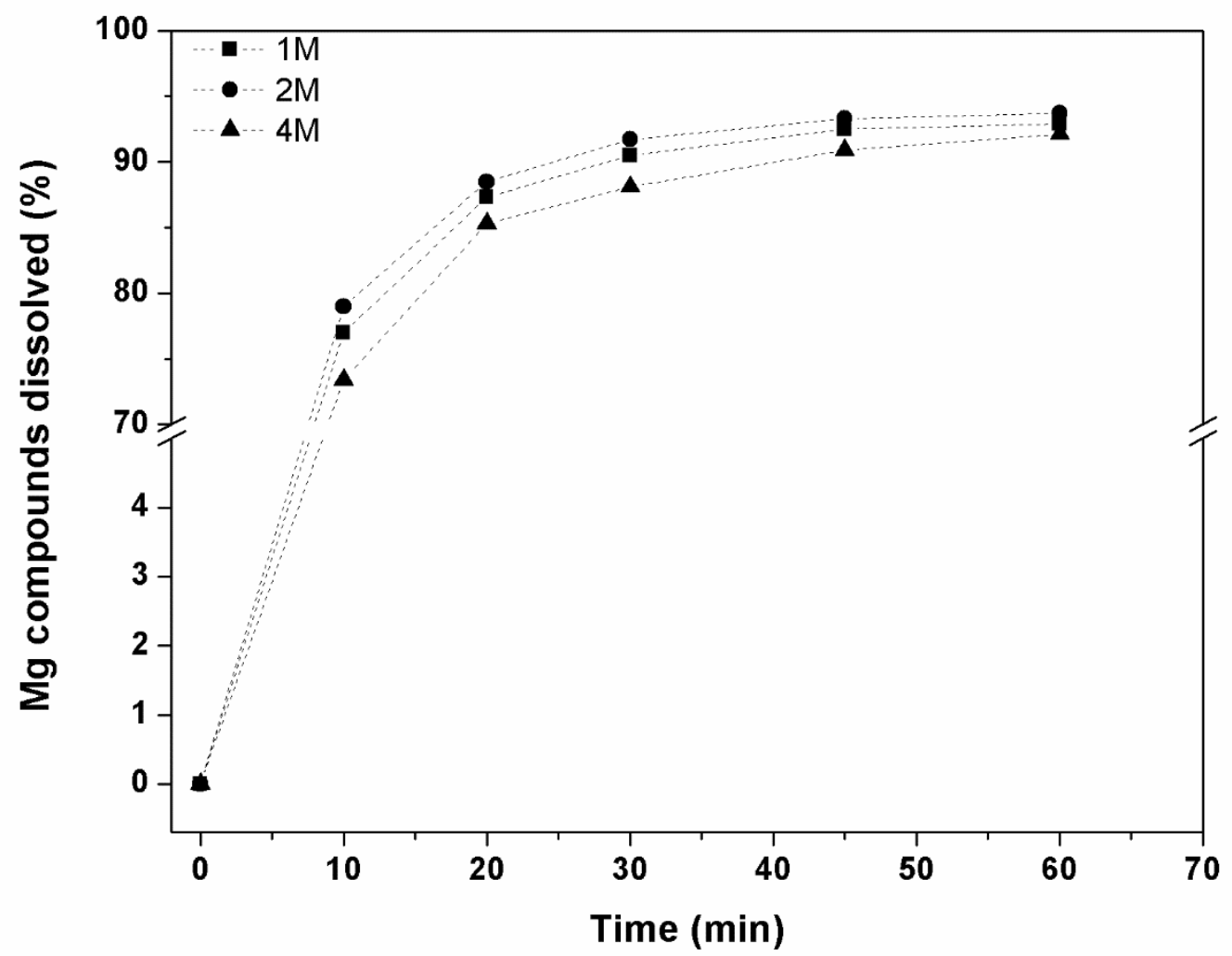

Figure 6. Dissolution of magnesium compounds with hydrochloric acid. Leaching temperature was $60^{\circ} \mathrm{C}$.

Although the leaching in hydrochloric acid proved to be efficient in removing $\mathrm{MgO}$ and $\mathrm{Mg}_{2} \mathrm{Si}, \mathrm{XRD}$ analysis of the leach residue revealed the presence of forsterite $\left(\mathrm{Mg}_{2} \mathrm{SiO}_{4}\right)$ and silica. The second stage of leaching in a mixture of $\mathrm{HF}+\mathrm{CH}_{3} \mathrm{COOH}$ under the previously discussed conditions removed these components.

\subsection{Characteristics of the silicon product}

A representative sample of the final silicon product after the above treatments is shown in

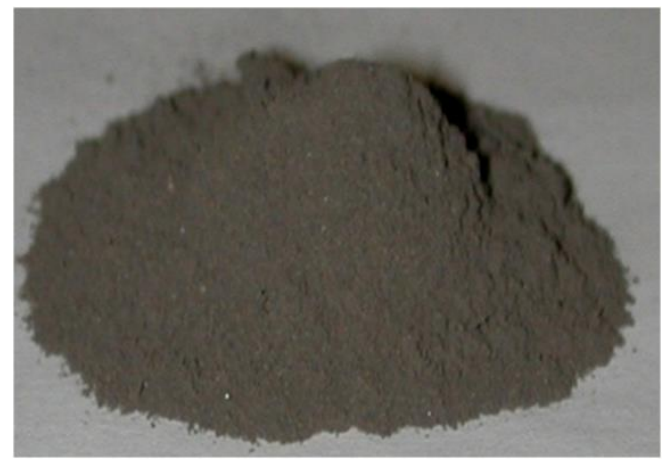


Figure 7. Size analysis of the powder shows particles within the range $0.2-250 \mu \mathrm{m}$ with a mean size of $56 \mu \mathrm{m}$. Clearly, the Si grains are larger than the starting silica fume particles, which is because of agglomeration of the particles during the reduction step. The exothermic nature of the reduction reaction can raise the temperature of the products well above the sintering temperature of silicon.

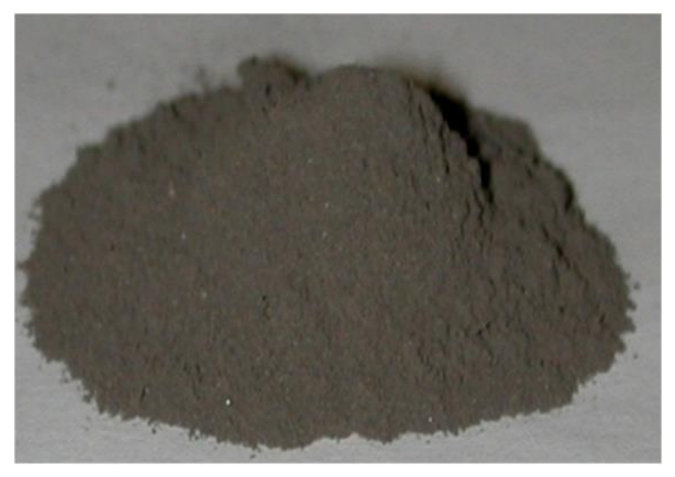

Figure 7. Silicon powder produced from silica fume.

Table 2 presents the ICP-AES analysis of a typical silicon sample obtained after acid purification. The overall purity is $>99.0 \mathrm{wt} \% \mathrm{Si}$, while some critical impurities such as phosphorous, boron and arsenic are favourably low, 12, <3, and 1 ppmw respectively.

Table 2. Chemical analysis of the Si product

\begin{tabular}{|c|c|c|c|}
\hline Elements & Concentration & Elements & Concentration \\
\hline $\mathrm{B}$ & $<3 *$ & $\mathrm{Ba}$ & 6 \\
\hline $\mathrm{P}$ & $<100 * / 12 * *$ & $\mathrm{Mg}$ & 3637 \\
\hline $\mathrm{Ca}$ & 1041 & $\mathrm{Cr}$ & 9 \\
\hline $\mathrm{Fe}$ & 1203 & Mo & 10 \\
\hline $\mathrm{Al}$ & 2255 & Mn & 150 \\
\hline $\mathrm{Ni}$ & 40 & $\mathrm{Zn}$ & 67 \\
\hline K & 1420 & V & 1 \\
\hline As & 1 & $\mathrm{Cd}$ & 3 \\
\hline
\end{tabular}




\section{DISCUSSION}

\subsection{Effectiveness of Primary Leaching-Roasting Purification}

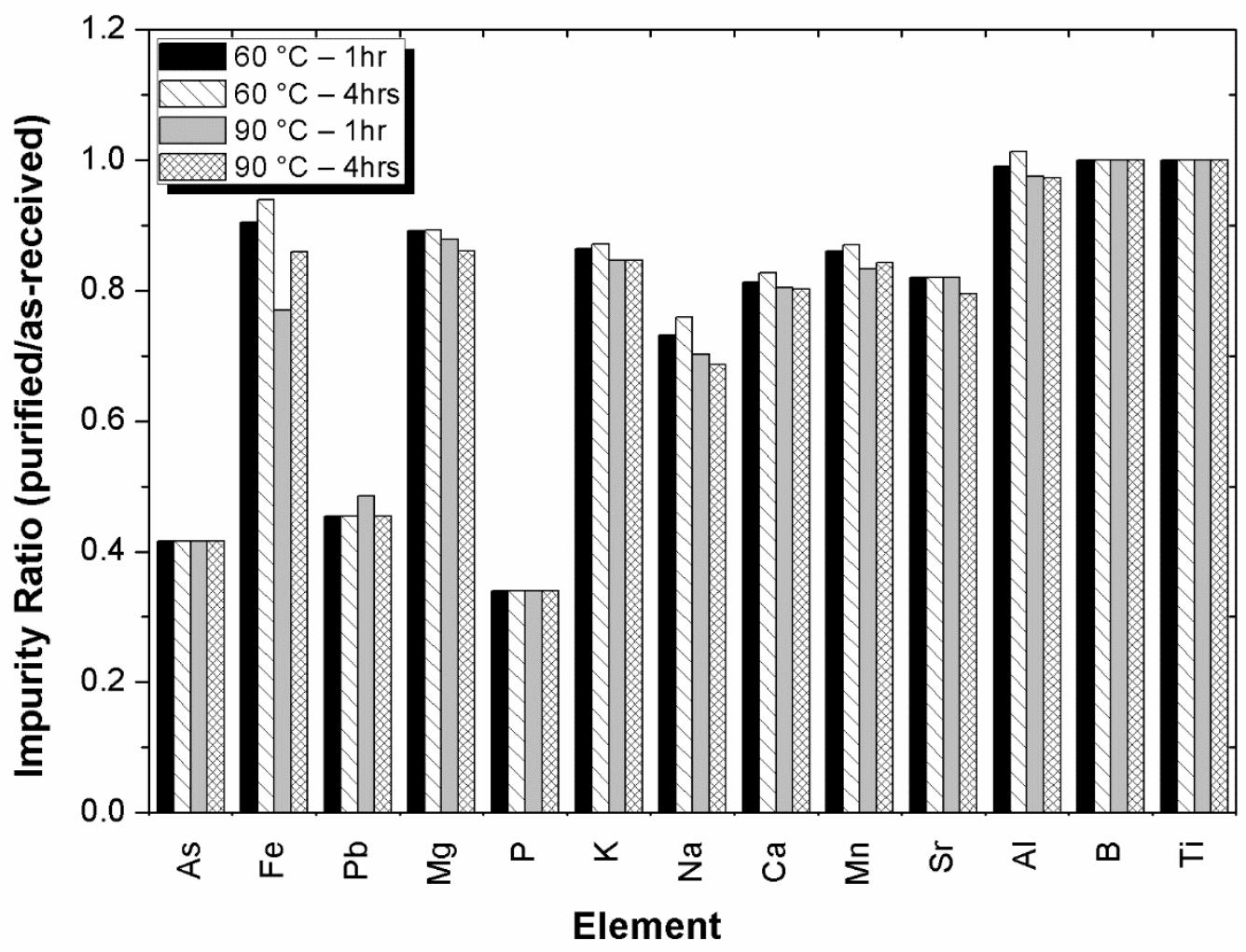

Figure 4 presents the ratio of impurity concentration for several elements before and after the leaching treatment. A smaller than unity ratio indicates removal of the element, the smaller the ratio, the greater the removal. As illustrated in this figure, some elements such as $\mathrm{P}, \mathrm{Pb}$, and As are removed to a large extent; $\mathrm{Fe}, \mathrm{Mg}, \mathrm{Na}$, and $\mathrm{K}$ are partially removed, while $\mathrm{Al}$ and Ti were not responsive to the treatment. The different response of various elements to acid leaching may be related to their respective condensation behaviour. While a large group of impurities ( $\mathrm{Fe}, \mathrm{Mg}$, $\mathrm{Al}$, etc.) are oxidized and condensed immediately after the mixing of off-gas with air, precipitation of the oxides of $\mathrm{P}, \mathrm{Pb}$, and $\mathrm{As}$ is delayed, due to their high vapour pressure (low boiling point). As a result, the former group of oxides are dispersed within the $\mathrm{SiO}_{2}$ particles while the latter group form a layer on the surface of the particles and become more responsive to 
the leaching treatment. Leaching at $90{ }^{\circ} \mathrm{C}$ for 4 hours provided maximum purification under the studied experimental conditions although the difference with other conditions was not substantial. Therefore, for economic reasons one may choose to perform the leaching at the milder conditions of $60^{\circ} \mathrm{C}$ for $1 \mathrm{~h}$.

As discussed earlier, the final carbon content of the silica fume was relatively large, 0.17 wt $\%$ after roasting at $700{ }^{\circ} \mathrm{C}$. It is believed that this unburnt carbon is in the form of silicon carbide, as otherwise it would have been readily oxidized under the experimental conditions.

\subsection{Optimum reduction conditions}

The yield of silicon, defined as the percent of initial $\mathrm{Si}$ (as $\mathrm{SiO}_{2}$ ) reduced to $\mathrm{Si}$ metal, was used as the measure for the determination of the optimum reduction conditions. Although the mechanism of the reduction is complex, involving gaseous $\mathrm{Mg}$ and reduction by $\mathrm{Mg}_{2} \mathrm{Si}$ as an intermediate phase, the following overall reactions are considered for the formation of $\mathrm{Si}, \mathrm{MgO}$, $\mathrm{Mg}_{2} \mathrm{Si}$, and $\mathrm{Mg}_{2} \mathrm{SiO}_{4}$.

$$
\begin{gathered}
2 \mathrm{Mg}+\mathrm{SiO}_{2}=2 \mathrm{MgO}+\mathrm{Si} \\
2 \mathrm{Mg}+\mathrm{Si}=\mathrm{Mg}_{2} \mathrm{Si} \\
2 \mathrm{MgO}+\mathrm{SiO}_{2}=\mathrm{Mg}_{2} \mathrm{SiO}_{4}
\end{gathered}
$$

Formation of magnesium silicide should be minimized as it lowers the Si yield and increases the consumption of magnesium. Although magnesium silicide is not thermodynamically stable in the presence of $\mathrm{SiO}_{2}$, its formation is due to kinetic limitations that prevent complete reduction of silica. Therefore, it is a combination of the kinetic factors (time and temperature) together with availability of $\mathrm{Mg}$ that leads to various amounts of $\mathrm{Mg}_{2} \mathrm{Si}$. The effects of these variables are discussed in the following sections. 


\subsubsection{Effect of $\mathrm{Mg} / \mathrm{SiO}_{2}$ ratio}

The Si yields calculated from the quantified XRD results show that a maximum is reached at a $\mathrm{Mg} / \mathrm{SiO}_{2}$ ratio of about 2:1 or the stoichiometric proportion, as depicted in
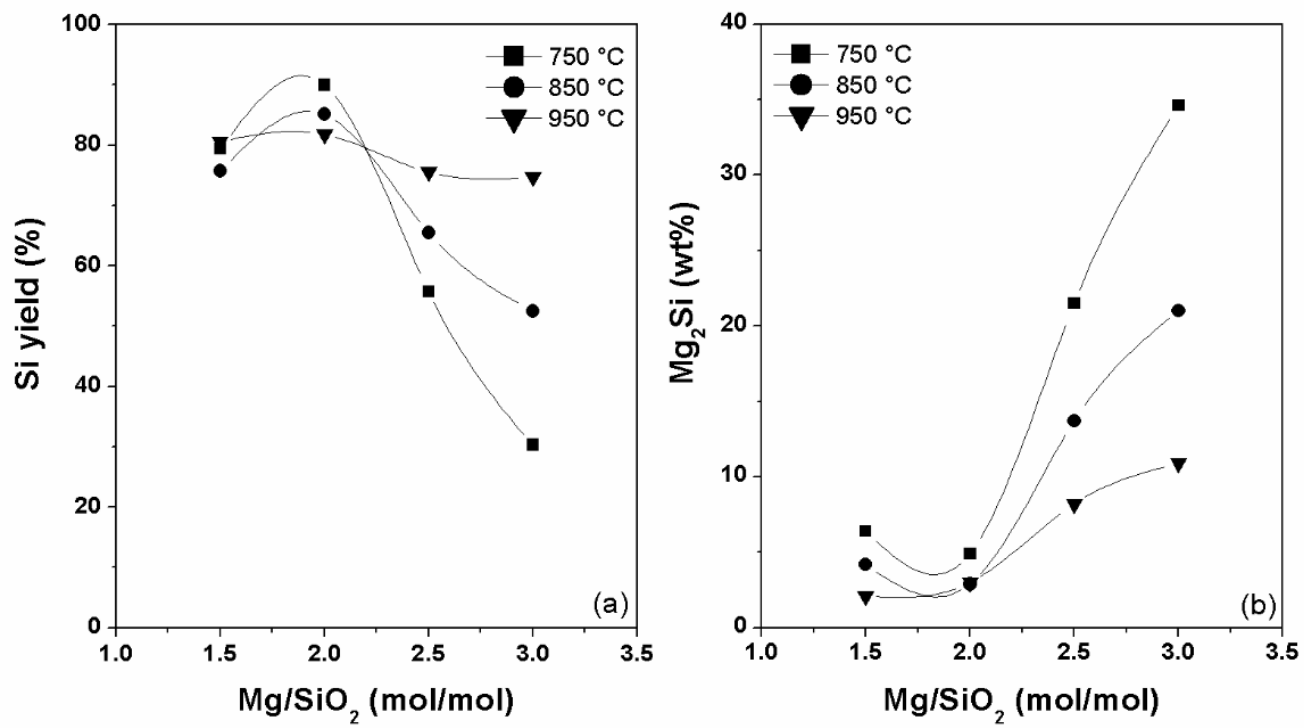

Figure $8 \mathrm{a}$. This is because at a lower ratio, $\mathrm{Mg}$ is not adequate to reduce $\mathrm{SiO}_{2}$ completely, whilst at $\mathrm{Mg} / \mathrm{SiO}_{2}>2.0$, excess magnesium consumes $\mathrm{Si}$ to form $\mathrm{Mg}_{2} \mathrm{Si}$ (Reaction 5). This is
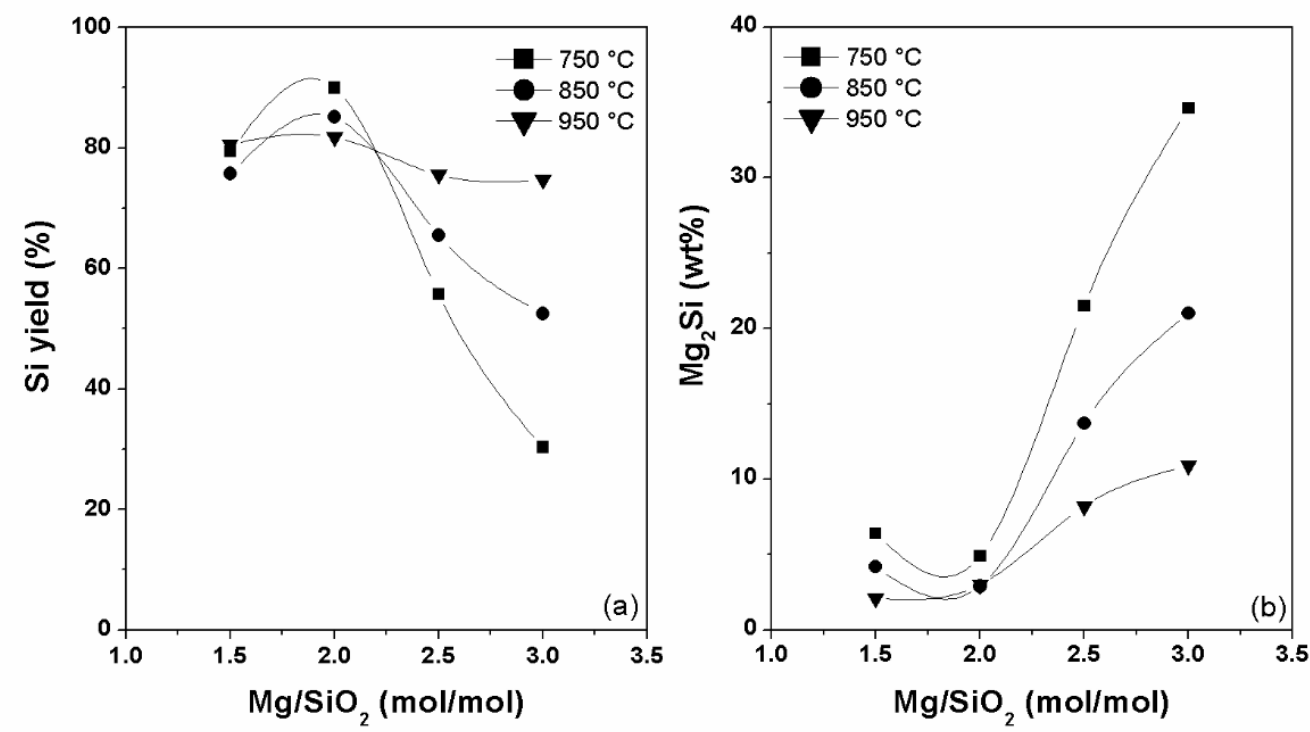

validated in 
Figure $8 \mathrm{~b}$ that shows formation of larger amounts of magnesium silicide when $\mathrm{Mg} / \mathrm{SiO} 2$ exceeds 2.0, for all temperatures.
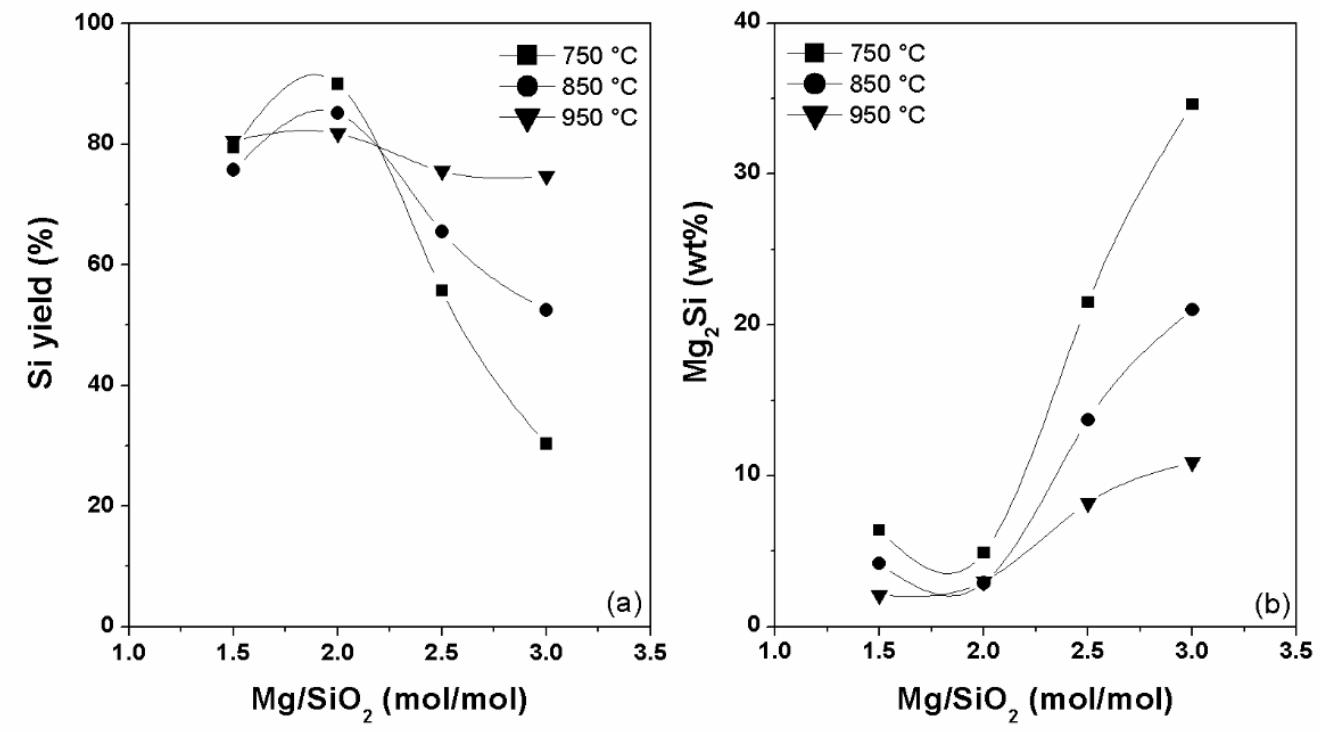

Figure 8. Effect of magnesium/silica ratio and temperature on (a) Si yield and (b) $\mathrm{Mg}_{2} \mathrm{Si}$ amount.

\subsubsection{Effect of temperature}

It is

evident

from
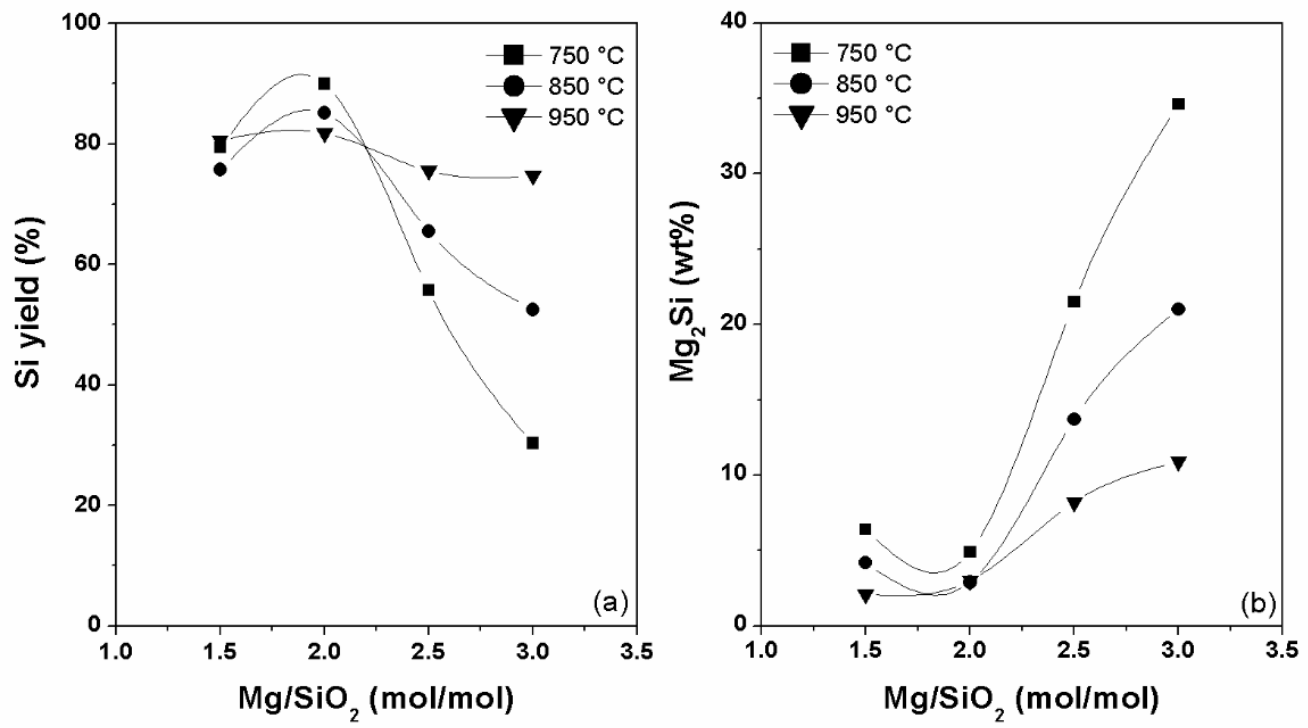
Figure $8 \mathrm{a}$ that for mixtures with $\mathrm{Mg} / \mathrm{SiO}_{2}$ below or equal to the stoichometric ratio (2.0), temperature has a relatively small effect on the $\mathrm{Si}$ yield. On the other hand, when the ratio exceeds this value, the effect of temperature becomes significant, yielding more silicon at higher temperatures.
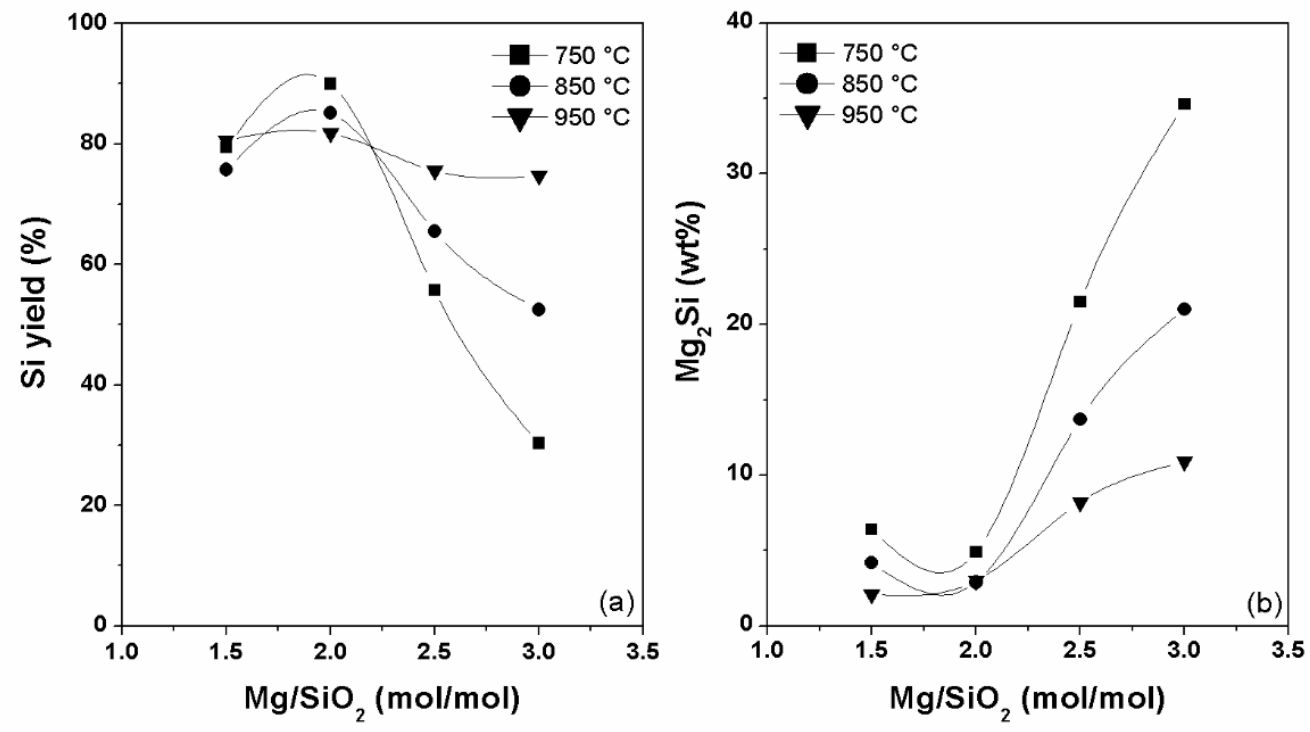

Figure $8 \mathrm{~b}$ reveals that this is because of a decrease in amount of $\mathrm{Mg}_{2} \mathrm{Si}$ formed at higher temperatures. Due to the accelerated kinetics of the reactions at higher temperatures, reduction by $\mathrm{Mg}_{2} \mathrm{Si}$ (Reaction 7) that requires solid state reaction or diffusion can take place to a greater extent, giving rise to more reduction of $\mathrm{SiO}_{2}$ at the expense of $\mathrm{Mg}_{2} \mathrm{Si}$. This is also consistent with 
the larger amounts of $\mathrm{Mg}_{2} \mathrm{Si}$ at lower temperatures
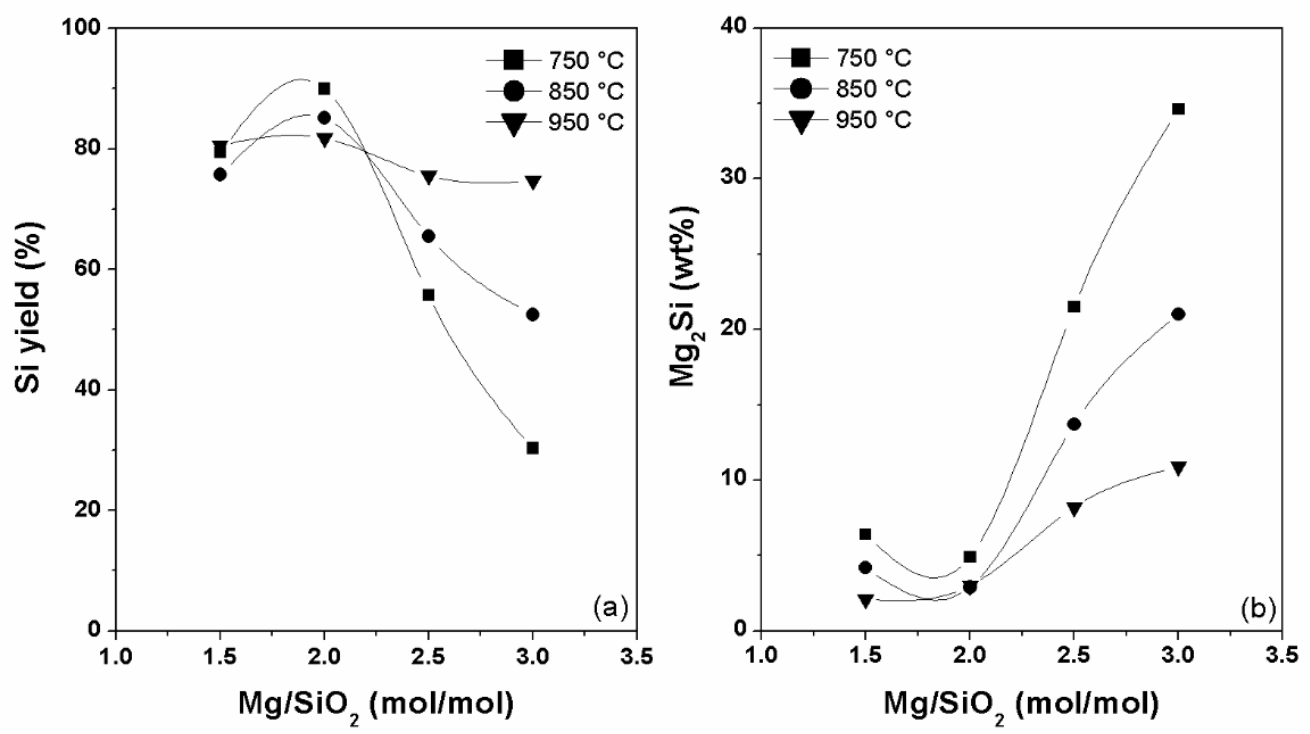

Figure 8b).

$$
\mathrm{Mg}_{2} \mathrm{Si}+\mathrm{SiO}_{2}=2 \mathrm{Si}+2 \mathrm{MgO}
$$
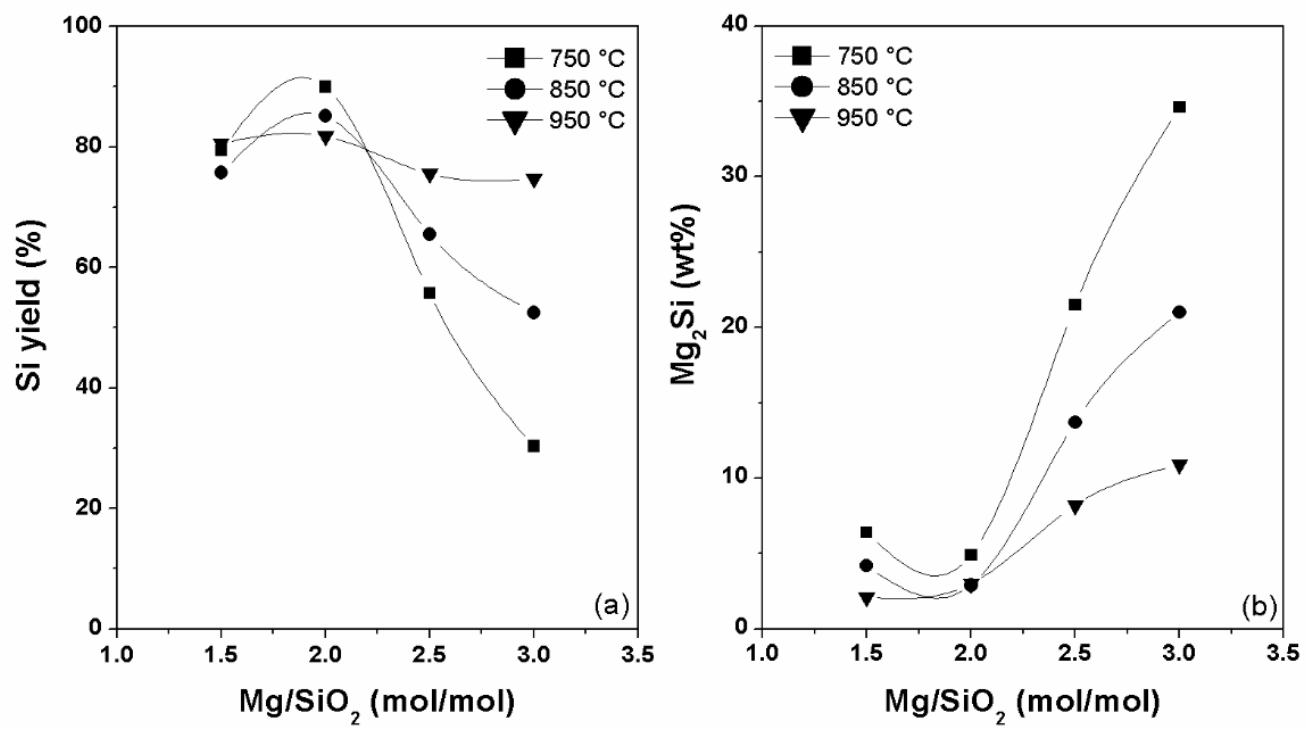

From 
Figure 8a, it appears that for the highest $\mathrm{Si}$ yield, the optimum reduction temperature and $\mathrm{Mg} / \mathrm{SiO}_{2}$ ratio are $750{ }^{\circ} \mathrm{C}$ and 2.0 respectively.

\subsubsection{Effect of hold time}

For several samples with fixed $\mathrm{Mg} / \mathrm{SiO}_{2}=2.0$, the hold time at $750{ }^{\circ} \mathrm{C}$ was varied from 0.5 to 3 hours. It was found that the Si yield increases from $55 \%$ at 0.5 hour to $90 \%$ at 2.0 hours and then tends to plateau for longer times. The increase in Si yield is associated with further completion of the reduction reactions that at some stages are controlled by solid state diffusion. Extending the time beyond 2 hours however, does not appear to significantly improve the yield because of the near complete reduction of $\mathrm{SiO}_{2}$ within the first two hours. 


\subsection{Kinetics of leaching of Mg compounds}

\subsubsection{Effect of Acid Concentration}

It

was

shown

in

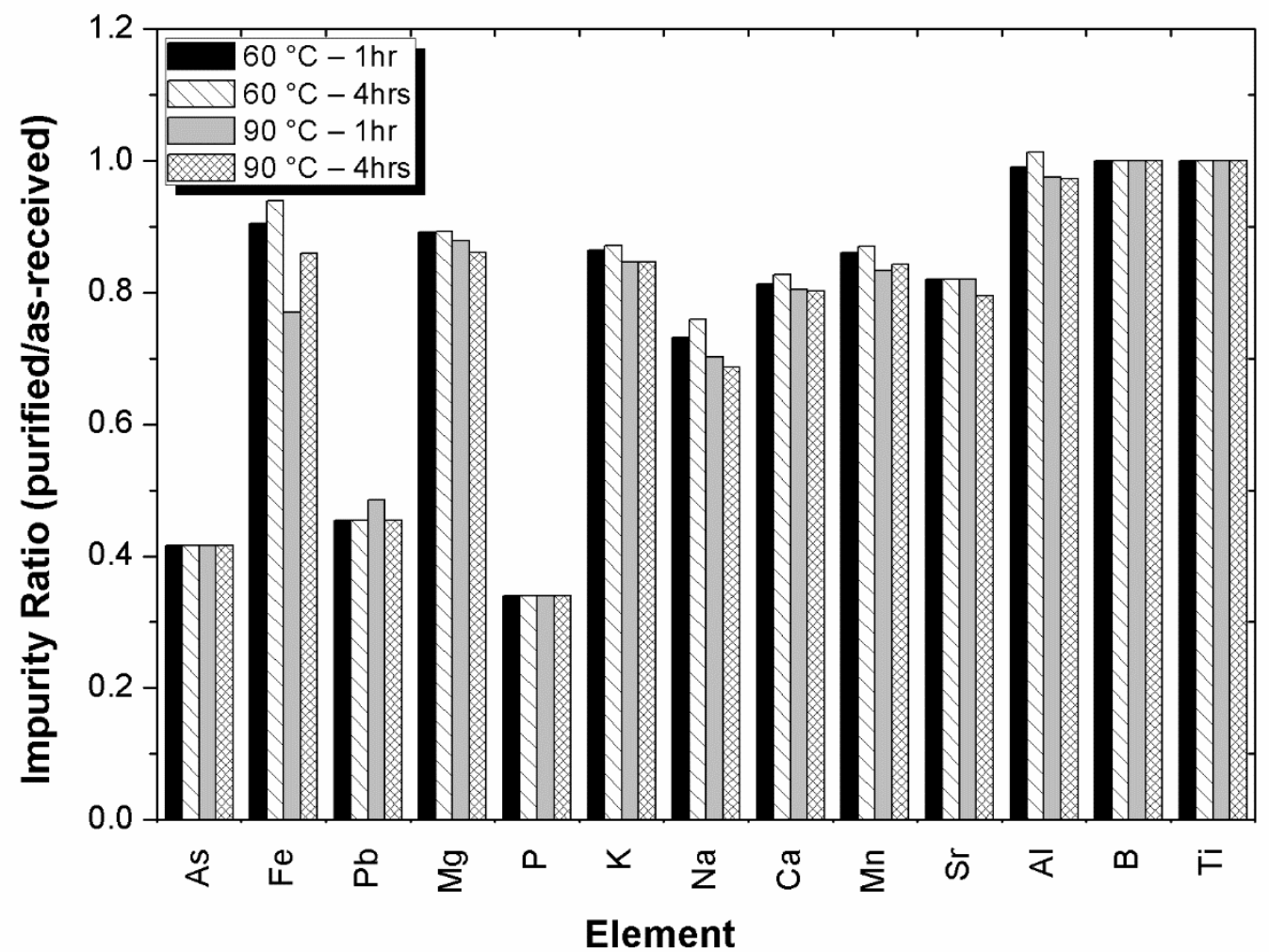

Figure 4 that the $2 \mathrm{M} \mathrm{HCl}$ leachant was more effective than the $1 \mathrm{M}$ and $4 \mathrm{M}$ solutions in dissolving the $\mathrm{Mg}$ compounds from the reaction products. The decrease in the rate of transfer of the magnesium to the solution observed with $4 \mathrm{M} \mathrm{HCl}$ concentration could be because of two effects (a) insufficient availability of hydrolyzed water to dissolve $\mathrm{Mg}$ compounds and (b) a quick reaction in the beginning that causes formation of an inhibiting $\mathrm{Mg}$-saturated layer around the particles. 


\subsubsection{Effect of Temperature}

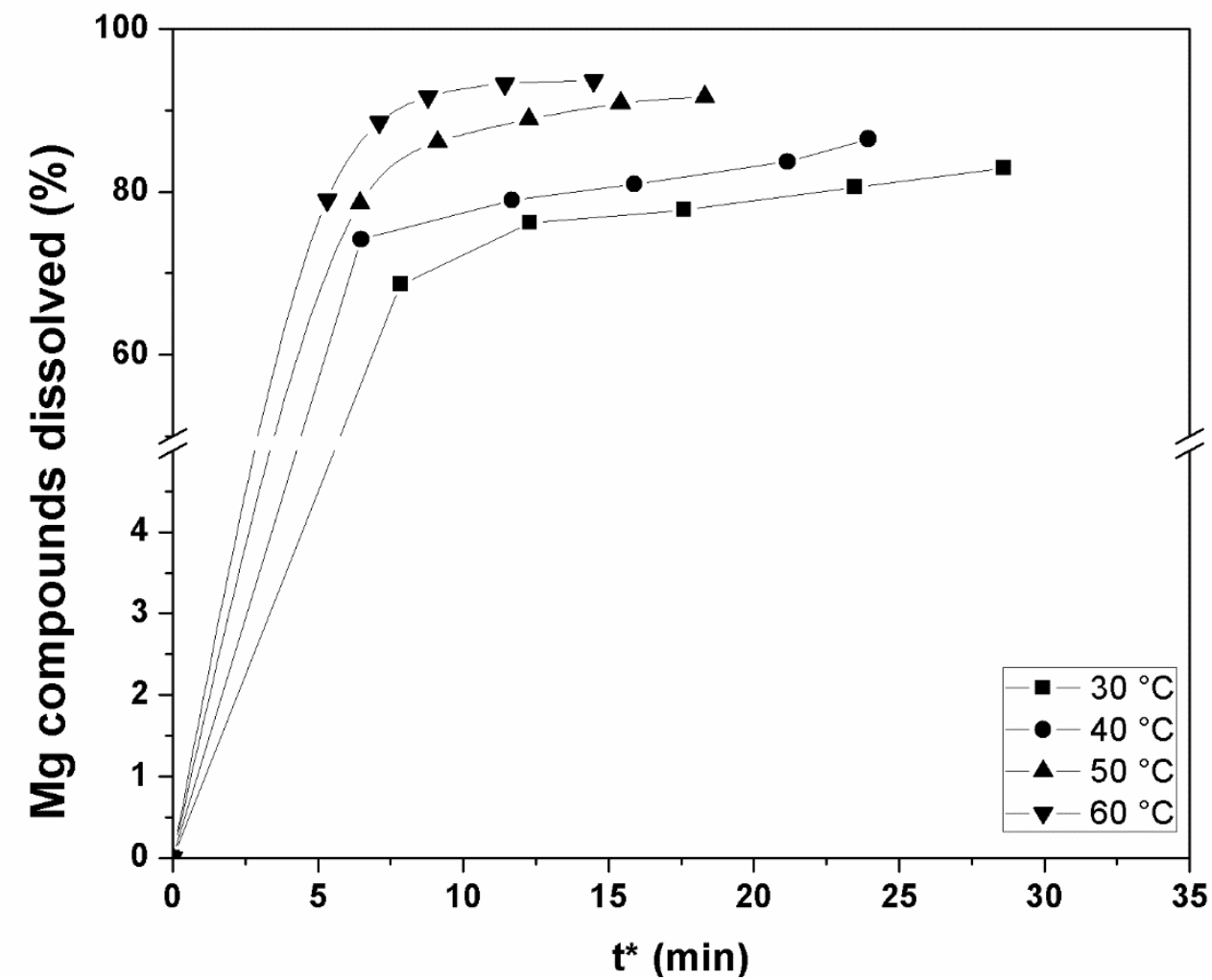

Figure 9 illustrates, temperature has a positive effect on both the extent and the rate of extraction of magnesium compounds. An analysis of the results showed that the leaching kinetics is consistent with mass transfer of $\mathrm{Mg}$ in the solution acting as the rate limiting step of the overall 
dissolution process. The dependence of the rate constant on temperature (

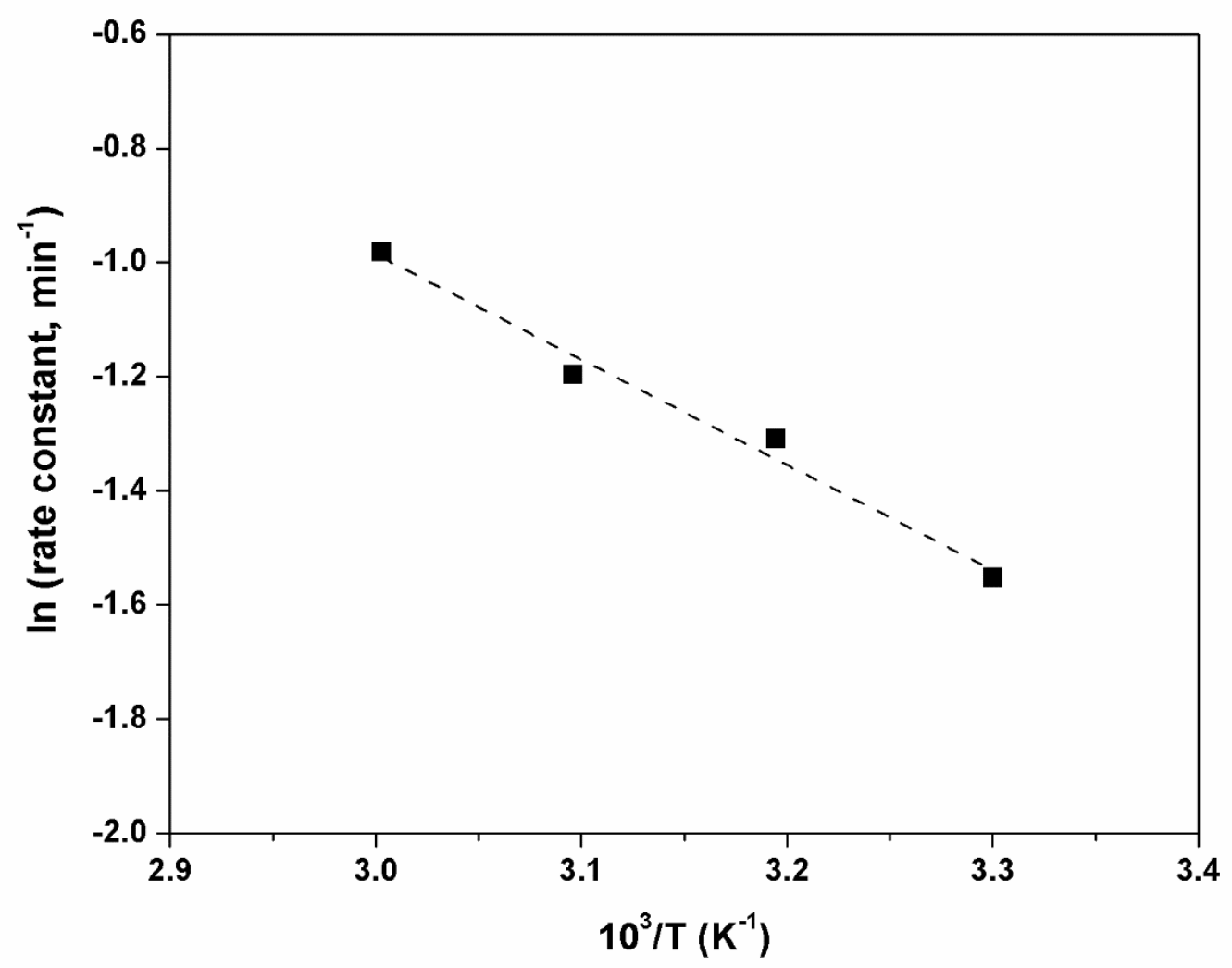

Figure 10) showed an activation energy in the range of $13-15 \mathrm{~kJ} / \mathrm{mol}$ for various acid concentrations, confirming that the transport of $\mathrm{Mg}$ into the solution controls the dissolution rate. 


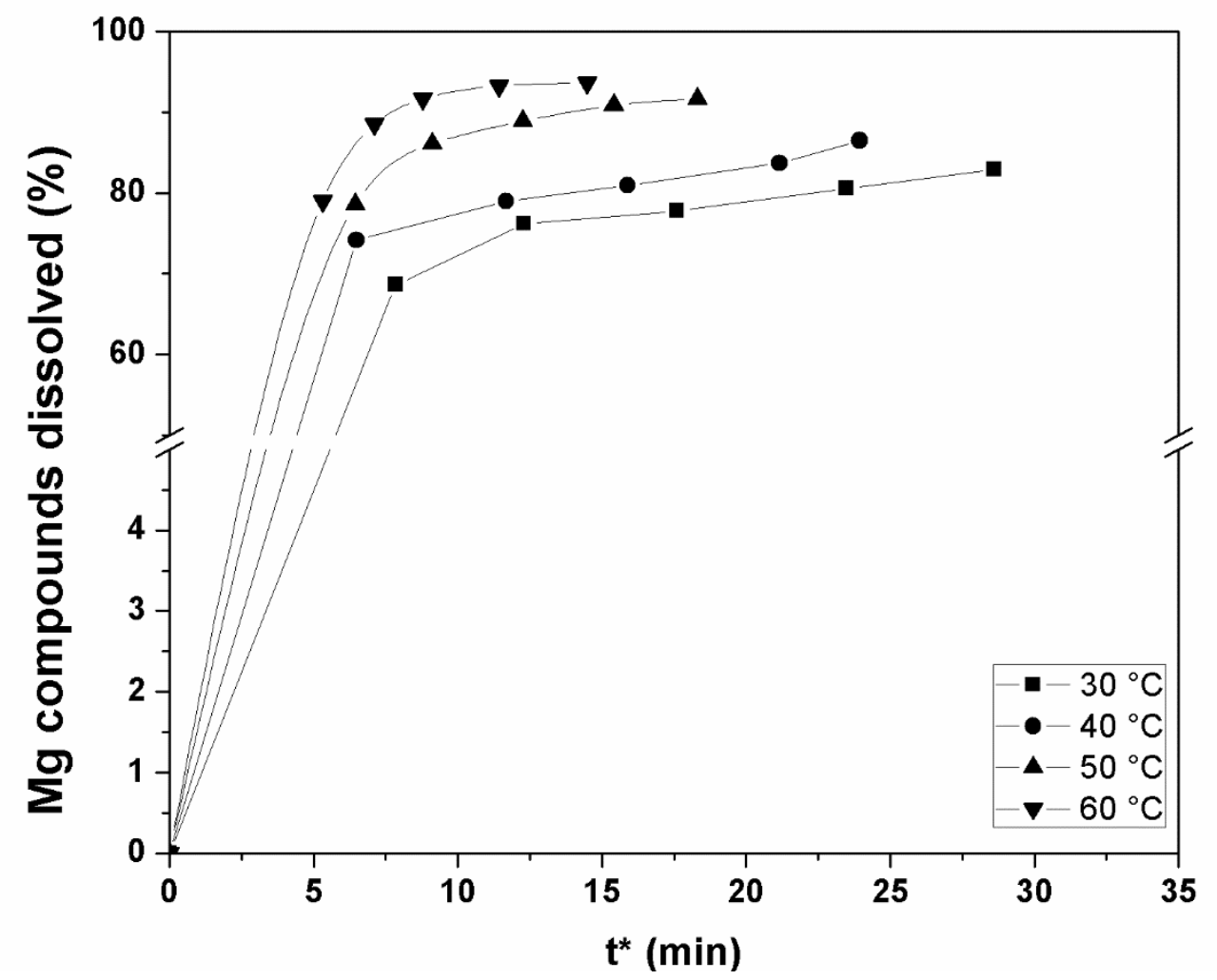

Figure 9. Effect of leaching temperature on dissolution of magnesium compounds $(2 \mathrm{M} \mathrm{HCl})$.

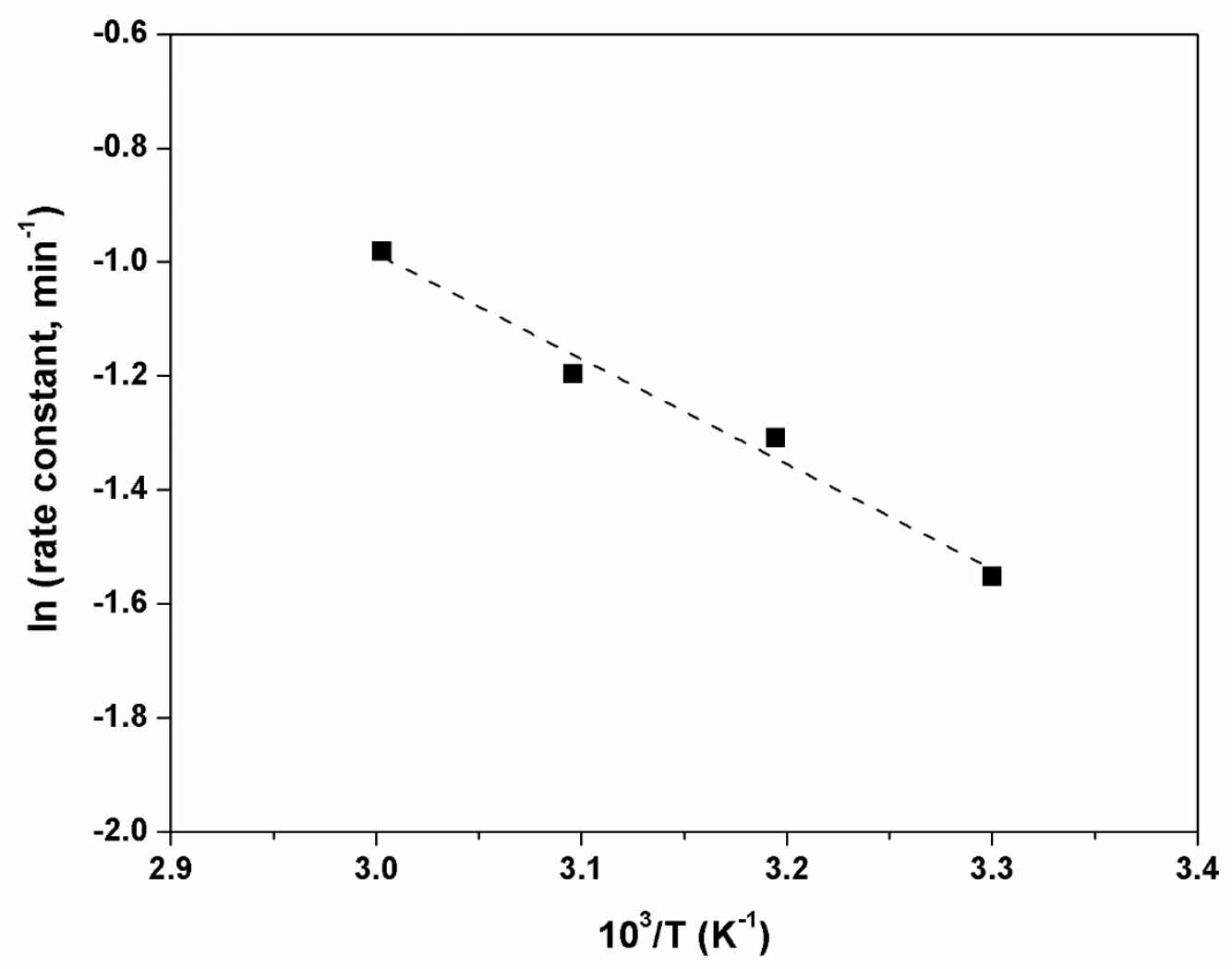

Page 28 of 34 
Figure 10. Temperature dependence of the rate constant.

\subsection{Suitability of the Si product as SoG-Si feedstock}

The chemical analysis of the produced Si in Table 2 presents much lower impurity levels than the metallurgical grade silicon, that is conventionally used for SoG-Si generation and contains typically 25-50 ppmw phosphorus and 6-50 ppmw boron [16].

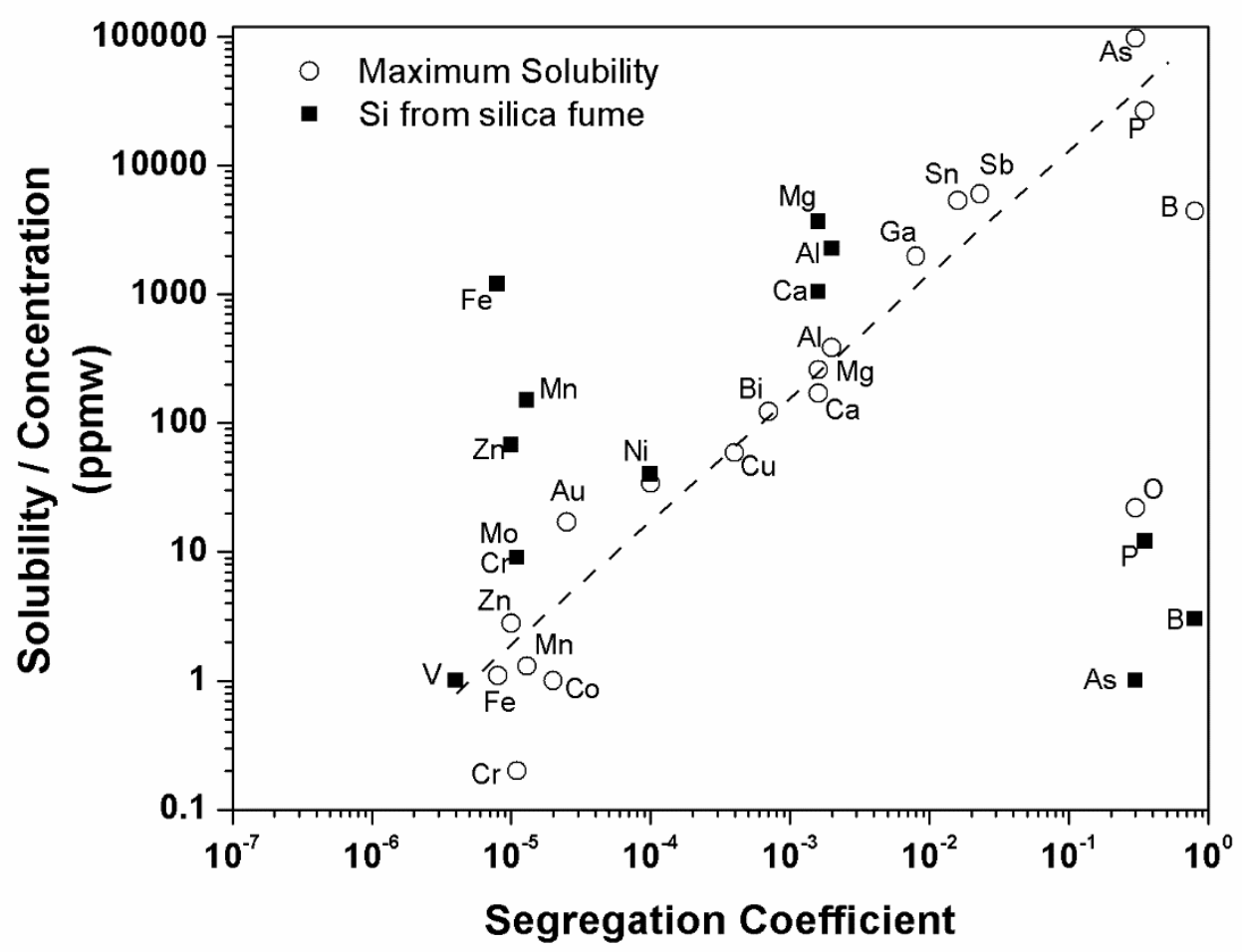

Figure 11Error! Reference source not found. shows correlation of solid solubility and segregation coefficient for different impurities in silicon [17]. Impurity level in the silicon powder produced in the present study is also superimposed on this figure (square symbols). It shows that for some of the most deleterious impurities such as As, $\mathrm{P}$, and B, the concentration is well below their solubility in $\mathrm{Si}$. For other impurities such as $\mathrm{Mg}, \mathrm{Al}, \mathrm{Fe}$, etc, the concentrations are substantially greater than the solubility limits. This indicates that these elements are most likely present along the grain boundaries or at the surface of the silicon grains. Therefore, they 
can be removed by melting, regrinding, and leaching of Si or controlled solidification methods such as unidirectional solidification. Furthermore, as seen in Table 2, the majority of the elements in high concentration ( $\mathrm{Ca}, \mathrm{Al}, \mathrm{K}, \mathrm{Mg}$ ) are those that form oxides more stable than silicon. It is thus anticipated that a simple oxidative treatment such as slag refining [18] can effectively eliminate these elements to levels required for SoG-Si application.

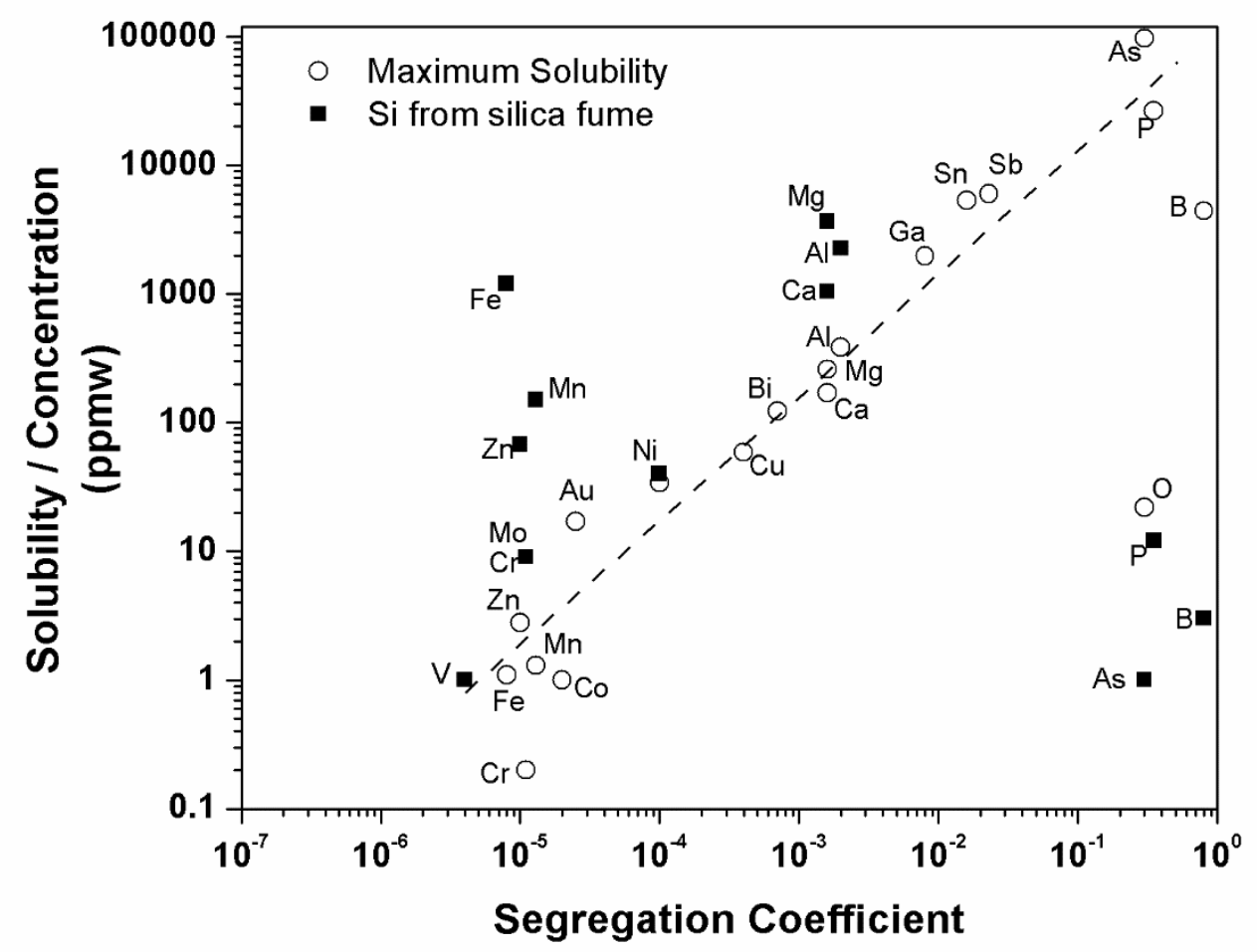

Figure 11. Impurity level in the silicon powder produced in this study ( $\mathbf{a})$ and maximum solid solubility (o) of various elements in Si (collected from [19-26] )

\section{CONCLUSIONS}

1. Characteristics of silica fume including large surface area, high silica content, low boron concentration and small particle size indicate its suitability as feedstock for production of high purity silicon.

2. Leaching of silica fume for 4 hours at $90{ }^{\circ} \mathrm{C}$ by $10 \% \mathrm{HCl}$ leachant proved more effective for impurity removal than lower temperatures and leaching time examined. Elements with low boiling point are more responsive to leaching. 
3. Under the experimental conditions of this research, the optimum conditions for reduction by magnesium of silica fume include: $\mathrm{Mg} / \mathrm{SiO}_{2}$ molar ratio of 2.0, temperature of $750{ }^{\circ} \mathrm{C}$, and hold time of 2 hours

4. Silica fume is a suitable feedstock for the generation of SoG-Si. Through the multi-step process of this work, Si with overall purity of over $99 \%$ with low P, $\mathrm{B}$, and As content was produced.

5. The major impurities present in the $\mathrm{Si}$ product are $\mathrm{Ca}, \mathrm{Al}, \mathrm{Mg}$, and $\mathrm{K}$ that can be readily removed by metallurgical refining techniques.

\section{AKNOWLEDGMENT}

The financial support for this research by Ontario Centres of Excellence and Process Research Ortech Inc. is greatly appreciated. S. Sadique would like to thank Y. Chaugule and Dr. M.D. Johnston for their assistance with leaching and chemical analysis.

\section{REFERENCES}

[1] A. Schei, J.K. Tuset, H. Tveit, Production of High Silicon Alloys, Tapir Forlag, Tronheim, 1998.

[2] B. Anderson, The Metallurgical Silicon Process Revisited, in: H.A. Øye, H. Brekken, L. Nygaard (Eds.) Silicon for the Chemical and Solar Industry X, Norwegian University of Science and Technology, Ålesund - Geiranger, Norway, 2010, pp. 11-23.

[3] T.C. Holland, Silica Fume User's Manual, in, Silica Fume Association, 2005.

[4] J. Wolsiefer, Ultra High-strength Field Placeable Concrete with Silica Fume Admixture, Concrete International: Design and Construction, 6 (1984) 25-31.

[5] D. Lynch, Winning the Global Race for Solar Silicon, Journal of Metals, 61 (2009) 41-48.

[6] R. Kvande, Solar Cells Manufactured from Silicon Made by the Solsilc Process, in: H.A. Øye, H. Brekken, L. Nygaard (Eds.) Silicon for the Chemical and Solar Industry X, Norwegian University of Science and Technology, Ålesund - Geiranger, Norway, 2010, pp. 191-201.

[7] H.D. Banerjee, S. Sen, H.N. Acharya, Investigations on the production of silicon from rice husks by the magnesium method, Materials Science and Engineering, 52 (1982) 173-179.

[8] D.N. Bose, P.A. Govindacharyulu, Progress in Solar-Grade Silicon from Rice Husk, in, Pergamon Press, Perth, Aust, 1984, pp. 2735-2739.

[9] A. Karera, S. Nargis, S. Patel, M. Patel, Silicon-based Materials from Rice Husk, Journal of Scientific and Industrial Research, 45 (1986) 441-448.

[10] K.K. Larbi, M. Barati, A. McLean, Reduction Behaviour of Rice Husk Ash for Preparation of High Purity Silicon, Metallurgical and Materials Transaction B, Submitted, July 2010 (2010).

[11] E.H. Myrhaug, H. Tveit, Material Balances of Trace Elements in the Ferrosilicon and Silicon Processes, in: Electric Furnace Conference, AIST Warrendale, PA, 2000, pp. 591-504.

[12] S. Brunauer, P.H. Emmett, E. Teller, Adsorption of Gases in Multimolecular Layers, Journal of the American Chemical Society, 60 (1938) 309-319. 
[13] D.L. Bish, S.A. Howard, Quantitative Phase Analysis Using the Rietveld Method, Journal of Applied Crystallography, 21 (1988) 86-91.

[14] S.K. Agarwal, Pozzolanic Activity of Various Siliceous Materials, Cement and Concrete Research, 36 (2006) 1735-1739.

[15] K.C. Nandi, D. Mukherjee, A.K. Biswas, H.N. Acharya, Optimization of Acid Concentration, Temperature and Particle size of Magnesium Silicide, Obtained from Rice Husk, for the Production of Silanes, Journal of Materials Science Letters, 12 (1993) 1248-1250.

[16] C.P. Khattak, D.B. Joyce, F. Schmid, Production of Solar Grade Silicon by Refining Liquid Metallurgical Grade Silicon, in, Crystal Systems Inc., Salem, Massachusetts, 2001.

[17] J. Dietl, Hydrometallurgical purification of metallurgical-grade silicon, Solar Cells, 10 (1983) 145154.

[18] M.D. Johnston, M. Barati, Distribution of Impurity Elements in Slag-Silicon Equilibria for Oxidative Refining of Metallurgical Silicon for Solar Cell Applications, Solar Energy Materials and Solar Cells, in press, doi:10.1016/j.solmat.2010.06.025 (2010).

[19] F.A. Trumbore, Solid Solubilities of Impurity Elements in Germanium and Silicon, Bell System Technical Journal, 39 (1960) 205-233.

[20] H. Sigmund, Solubilities of Magnesium and Calcium in Silicon, Journal of The Electrochemical Society, 129 (1982) 2809-2812.

[21] R.H. Hopkins, Effect of Impurities on Silicon Solar-cell Performance, in: Flat-plate Solar Array Project Worskshop on Low-cost Polysilicon for Terrestrial Photovoltaic Solar Cell Applications, JPL, Las Vegas, Nevada, 1986, pp. 15-36.

[22] L. Ottem, Solubility and Thermochemical Data of Oxygen and Carbon in Liquid Alloys of Silicon and Ferrosilicon, in, SINTEF, Trondheim, Norway, 1993.

[23] W. Lin, D.W. Hill, Oxygen segregation in Czochralski silicon growth, Journal of Applied Physics, 54 (1983) 1082-1085.

[24] J.H. Aalberts, M.L. Verheijke, The Solid Solubility of Nickel in Silicon Determined by Neutron Activation Analysis, Applied Physics Letters, 1 (1962) 19-20.

[25] H. Feichtinger, R. Czaputa, Energy Levels and Solubility of Interstitial Chromium in Silicon, Applied Physics Letters, 39 (1981) 706-708.

[26] M.K. Bakhadyrkhanov, B.I. Boltaks, G.S. Kulikov, Diffusion, Electrotransport, and Solubility of Manganese Impurities in Silicon, Soviet Physics - Solid State, 14 (1972) 1441-1444.

\section{List of Figures}

Figure 1. Process flowsheet for production of SoG-Si from silica fume . 


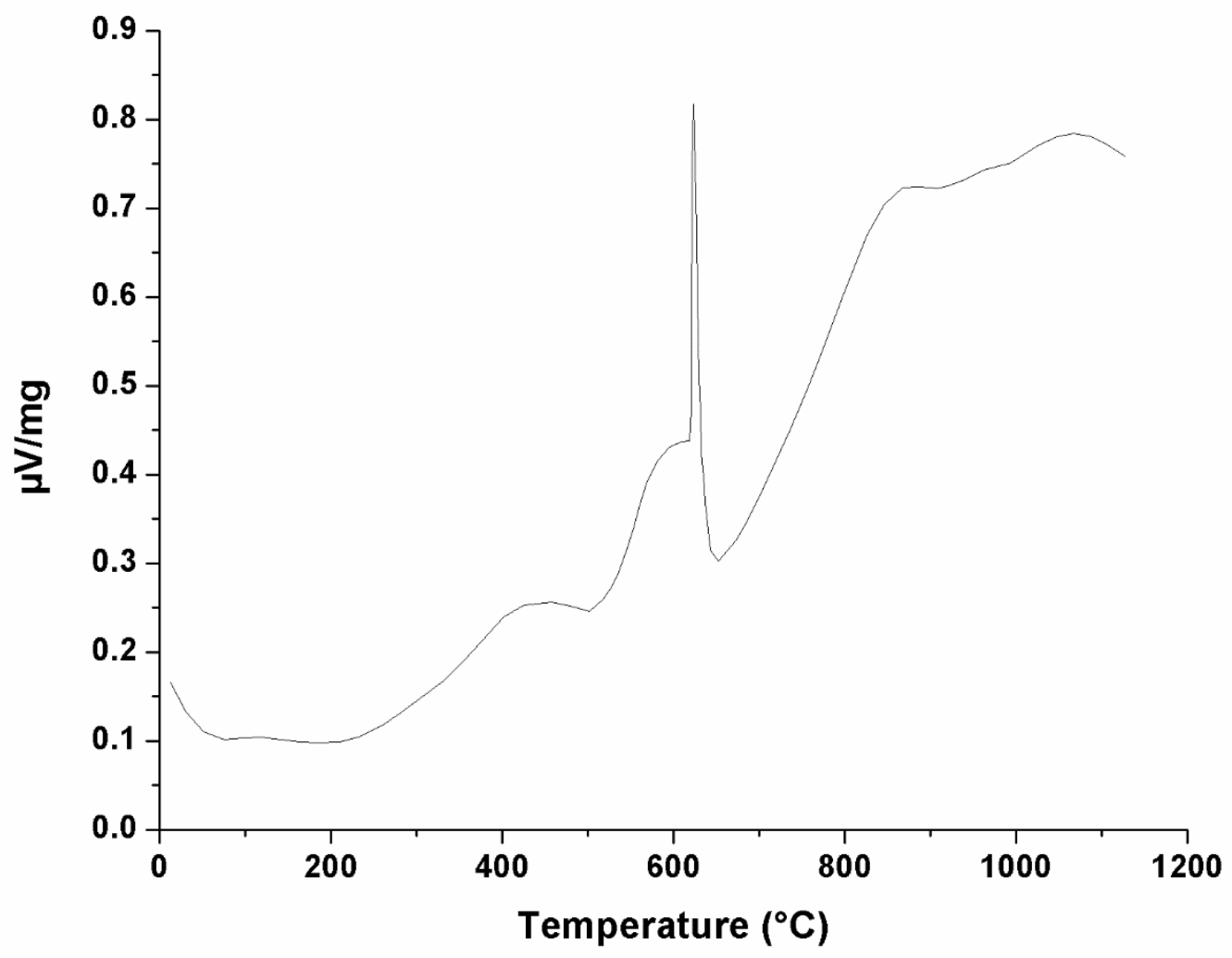

Figure 2. DTA spectrum for a mixture of silica fume and $\mathrm{Mg}$.

Figure 3. (a) Particle size distribution and (b) XRD spectrum of as-received silica fume.

Figure 4. Effect of leaching treatment on removal of impurities. 


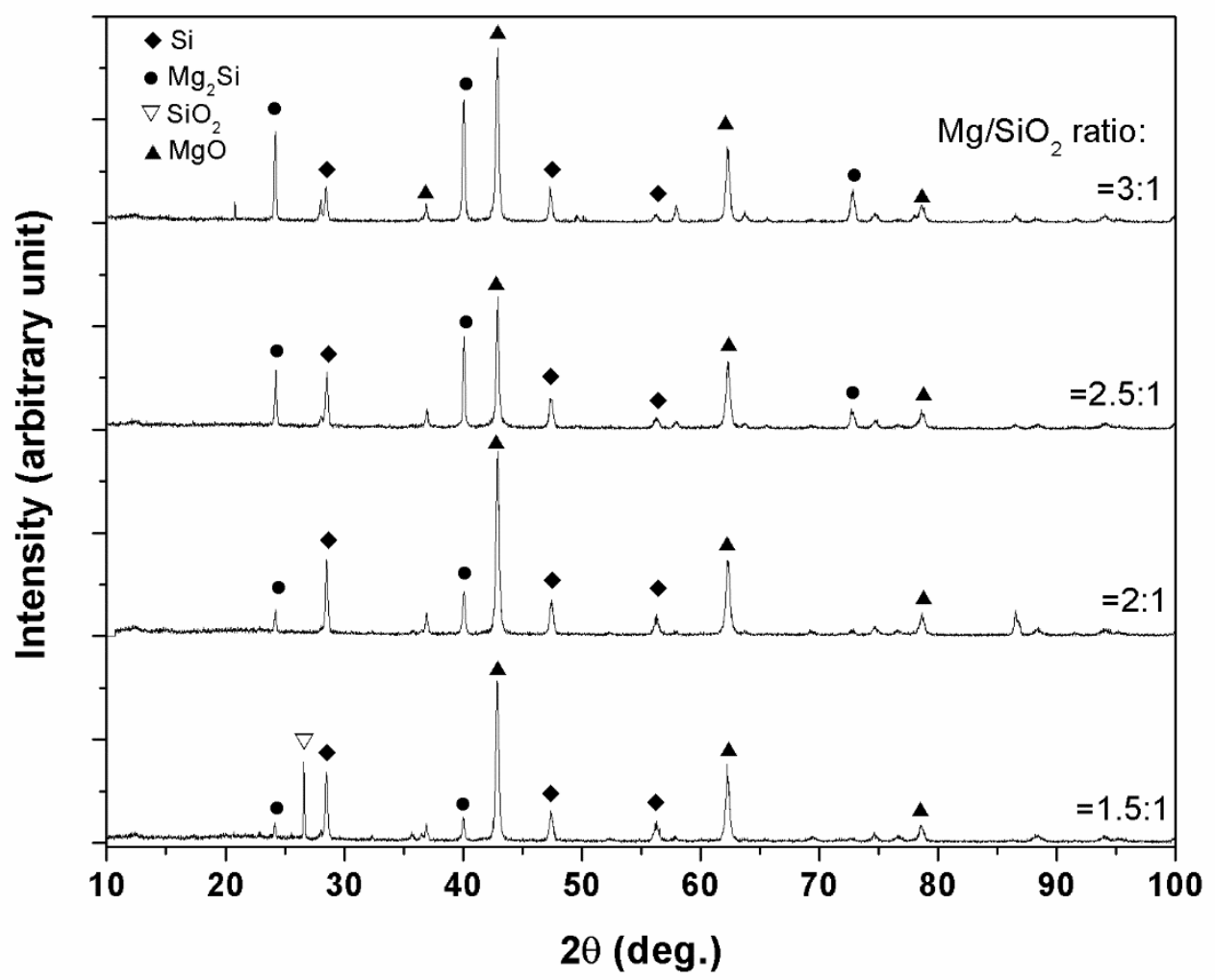

Figure 5. Effect of magnesium/silica ratio on the XRD spectrum of samples reduced at $750^{\circ} \mathrm{C}$ for 2 hours.

Figure 6. Dissolution of magnesium compounds with hydrochloric acid. Leaching temperature was $60^{\circ} \mathrm{C}$.

Figure 7. Silicon powder produced from silica fume.

Figure 8. Effect of magnesium/silica ratio and temperature on (a) Si yield and (b) $\mathrm{Mg}_{2} \mathrm{Si}$ amount.

Figure 9. Effect of leaching temperature on dissolution of magnesium compounds $(2 \mathrm{M} \mathrm{HCl})$.

Figure 10. Temperature dependence of the rate constant.

Figure 11. Impurity level in the silicon powder produced in this study ( $\mathbf{a})$ and maximum solid solubility (०) of various elements in $\mathrm{Si}$ (collected from [19-26] ) 